\title{
Technology Forgiveness: Why emerging technologies differ in their resilience to institutional instability
}

\section{Citation for published version (APA):}

Bonnin Roca, J., Vaishnav, P., Morgan, M. G., Fuchs, E., \& Mendonça, J. (2021). Technology Forgiveness: Why emerging technologies differ in their resilience to institutional instability. Technological Forecasting and Social Change, 166, [120599]. https://doi.org/10.1016/j.techfore.2021.120599

\section{Document license:}

TAVERNE

DOI:

10.1016/j.techfore.2021.120599

Document status and date:

Published: 01/05/2021

\section{Document Version:}

Publisher's PDF, also known as Version of Record (includes final page, issue and volume numbers)

\section{Please check the document version of this publication:}

- A submitted manuscript is the version of the article upon submission and before peer-review. There can be important differences between the submitted version and the official published version of record. People interested in the research are advised to contact the author for the final version of the publication, or visit the $\mathrm{DOI}$ to the publisher's website.

- The final author version and the galley proof are versions of the publication after peer review.

- The final published version features the final layout of the paper including the volume, issue and page numbers.

Link to publication

\section{General rights}

Copyright and moral rights for the publications made accessible in the public portal are retained by the authors and/or other copyright owners and it is a condition of accessing publications that users recognise and abide by the legal requirements associated with these rights.

- Users may download and print one copy of any publication from the public portal for the purpose of private study or research.

- You may not further distribute the material or use it for any profit-making activity or commercial gain

- You may freely distribute the URL identifying the publication in the public portal.

If the publication is distributed under the terms of Article 25fa of the Dutch Copyright Act, indicated by the "Taverne" license above, please follow below link for the End User Agreement:

www.tue.nl/taverne

Take down policy

If you believe that this document breaches copyright please contact us at:

openaccess@tue.nl

providing details and we will investigate your claim. 


\title{
Technology Forgiveness: Why emerging technologies differ in their resilience to institutional instability
}

\author{
Jaime Bonnín Roca $^{\mathrm{a}, *}$, Parth Vaishnav ${ }^{\mathrm{b}}$, Granger M. Morgan ${ }^{\mathrm{c}}$, Erica Fuchs ${ }^{\mathrm{c}}$, Joana Mendonça ${ }^{\mathrm{d}}$ \\ ${ }^{a}$ Eindhoven University of Technology, Department of Industrial Engineering \& Innovation Sciences, P.O. Box 513, 5600, MB, Eindhoven, The Netherlands \\ ${ }^{\mathrm{b}}$ School for Environment and Sustainability, University of Michigan, 440 Church Street Ann Arbor, Michigan 48109, United States of America \\ ${ }^{\mathrm{c}}$ Department of Engineering and Public Policy, Carnegie Mellon University, 5000 Forbes Avenue, Pittsburgh, Pennsylvania 15213, United States of America \\ d Center for Innovation, Technology and Policy Research, IN+, Instituto Superior Técnico, University of Lisbon, Av. Rovisco Pais 1, Lisbon 1049-001, Portugal
}

\section{A R T I C L E I N F O}

\section{Keywords:}

Additive manufacturing

Technological uncertainty

Institutional instability

Latecomer countries

Technology adoption

Technological upgrading

\begin{abstract}
A B S T R A C T
Long-term public support may encourage the diffusion of emerging technologies by coordinating the generation of knowledge and providing patient funding, but unexpected policy changes may hinder private investment and even lead to situations of technology lockout. Leveraging archival data; insights from 45 interviews across academia, industry, and government; and 75 hours of participant observations, we develop insights about why institutional instability in Portugal affected the adoption of Polymer Additive Manufacturing (PAM) and Metal Additive Manufacturing (MAM) differently. In both cases, Portugal invested in the technology relatively early. While PAM has been widely adopted, including increasingly in high-tech applications, MAM adoption has been modest despite MAM's potential to greatly improve the performance and competitiveness of metal molds. From the comparison between PAM and MAM, we generate theory about technological and contextual factors that affect 'technological forgiveness', defined as the resilience of a new technology's adoption to institutional instability.
\end{abstract}

\section{Classification codes}

O250 Industrial Policy

O310 Innovation and Invention: Processes and Incentives

O320 Management of Technological Innovation and R\&D

O330 Technological Change: Choices and Consequences; Diffusion Processes

O380 Technological Change: Government Policy

\section{Introduction}

Scholars have identified a host of competing factors that determine why diffusion rates vary across technologies (Hall, 2004; Mansfield, 1961; Marinakis, 2012; Rosenberg, 1972). Firms face high levels of market and technological uncertainty when adopting an emerging technology (Nelson and Winter, 1982; Tassey, 1997). Diffusion may be particularly slow in cases where capital costs are high, technical complexity is high and there are few opportunities for experimentation (Goldfarb, 2005; Rogers, 2003). An important set of emerging technologies with high capital costs and high initial uncertainty is process-based (in contrast to assembly-based) technologies such as chemicals (Pisano,
1997), photonics (Fuchs and Kirchain, 2010) and electronic semiconductors (Bohn, 1995; Holbrook et al., 2000), pharmaceuticals (Pisano, 1991), or additive manufacturing (Baumers et al., 2016; Bonnín Roca et al., 2017).

To counteract firms' risk-aversion, public support can play an important role in supplementing private investment in innovative activities, creating organizations and fostering networks for the generation of new knowledge, and supplementing private R\&D efforts with additional funding mechanisms (Lerner, 1996; Lynn et al., 1996; Martin and Scott, 2000). In addition, government can foster the creation of consortia to develop sectorial roadmaps which decrease risks in disruptive technologies by increasing coordination among public and private stakeholders (Tierney et al., 2013; Walsh, 2004). However, firms may not trust governments if their actions lack public legitimacy, which is usually earned through long periods of stable support (Oliver, 1991; Zucker et al., 2002). Volatility in funding and continuous policy changes may erode trust and hinder private investment (Aldrich and Fiol, 1994; Henisz, 2002; Mowery et al., 2010). In that case, emerging technologies may become locked out even when they are technically superior to the incumbent technology (Arthur, 1989; Cusumano et al., 1992; Schilling,

\footnotetext{
* Corresponding author.

E-mail address: j.bonnin.roca@tue.nl (J. Bonnín Roca).
} 
1998).

In this paper, we aim to better understand the relationship between the characteristics of a technology, and how institutional stability affects technology diffusion. We define institutional instability as unexpected change in policies or organizational structures including, but not limited to: changes in borrowing rates and $\mathrm{R} \& \mathrm{D}$ funding pools; changes in national and supranational policy goals; reorganization, emergence or disappearance of national laboratories and regional research and technology organizations; all of which appear in our case. We study the adoption of two emerging technologies - polymer (PAM) and metal (MAM) additive manufacturing- between 1990 and 2015 in Portugal, a high-income technology follower which experienced additional resource constraints as a result of the 2010 financial crisis. The use of additive manufacturing technologies has boomed in the last decade (Maresch and Gartner, 2020), and is expected to bring large societal changes both to high-tech and low-tech industries in the long term (Bogers et al., 2016; Jiang et al., 2017). We focus our work on the Portuguese molds industry, a sector in which the country's industry is globally competitive (CEFAMOL, 2017; Santos, 2009). This sector is the leading user of PAM and MAM in Portugal.

We present and compare a pair of longitudinal case studies (Eisenhardt, 1989; Yin, 2013) in which we triangulate insights from archival data (on Portuguese macroeconomic conditions and research institutions, and activities in PAM and MAM), together with results from 45 interviews, and 75 hours of participant observations (Jick, 1979) to reconstruct the history of both PAM and MAM technologies in Portugal.

We find that in both cases, Portugal invested relatively early in the technology. Both PAM and MAM suffered from institutional instability at the regional, national and European levels. However, while the country has been able to develop a robust PAM knowledge base and transition to high-end applications, MAM's adoption remains low and the presently comes close to being in a state of technology lockout (Arthur, 1989; Schilling, 1998). We analyze how changes in macroeconomic conditions and funding programs may have affected MAM more than PAM. From a technical perspective, MAM presents higher levels of technological uncertainty than PAM.

From the comparison between PAM and MAM, we generate theory about which technological and contextual factors affect their 'technological forgiveness', defined as the resilience of the adoption process for a new technology in the face of institutional instability. We create a framework where forgiveness depends on technology-level and industry-level risks. Policymakers may use our framework to assess the extent of institutional stability necessary for a technology to be successfully adopted in a specific industrial context. Countries investing in technologies that are less-forgiving in the face of institutional instability need to establish long-term policies to secure private investment and the development of the national know-how, and explore the possibility of applying the same technology in less challenging industrial applications.

\section{Theoretical background: institutional support for technology diffusion}

\subsection{Factors explaining variance in technology diffusion rates}

The diffusion of a new technology is usually a slow process, given the existence of large amounts of technical and market uncertainty (Nelson and Winter, 1982; Tassey, 1997). Scholars have identified a host of competing factors that may influence the rate of technology diffusion (Hall, 2004; Mansfield, 1961; Marinakis, 2012; Rosenberg, 1972). Empirical studies suggest that diffusion will be faster in cases with larger (Acemoglu and Linn, 2004; Desmet and Parente, 2010) and more diverse markets (Gross, 2017), and where the expected profitability (Rogers, 2003) or number of users is higher (Bresnahan et al., 1996; Griliches, 1957; Mansfield, 1961). It is also widely accepted that the existing institutional framework can exert strong pressures on the diffusion of the technology (DiMaggio and Powell, 1983, 1983; Hall, 2004; Nelson,
1994, 1982; Rogers, 2003; Rosenberg, 1972). Less studied is how the diffusion rates of different technologies might be affected differently by sudden, unforeseen changes in those institutions.

Technology diffusion may be particularly challenging in cases where technical complexity, and thus technological uncertainty, is high (Goldfarb, 2005; Rogers, 2003). Early-stage products whose innovations are based on new materials or new chemical processes (in contrast to assembly) represent an important class of technologies for which diffusion may thus be particularly challenging. For products with material and process-based innovations in their early stages, knowledge is tacit or otherwise costly to transfer (de Solla Price, 1984; Johnson et al, 2002; Polanyi, 1958; von Hippel, 1994) and production exhibits particularly high uncertainty. Examples of such products include chemicals (Pisano, 1997), photonics (Fuchs and Kirchain, 2010) and electronic semiconductors (Bohn, 1995; Holbrook et al, 2000), pharmaceuticals (Pisano, 1991), and additive manufacturing (Bonnín Roca et al., 2017). In these products, the level of technological uncertainty depends on a number of factors such as the number of variables and the interaction among them (Macher, 2006); the number of subcomponents (Singh, 1997); need for complementary innovation (e.g. need for new testing techniques, procedures or process control mechanisms) (Brown and Duguid, 2001; Fleck, 1994; Lécuyer, 2006; Pisano, 1997); and the importance of 'learning by using' (Mowery and Rosenberg, 1981). Higher uncertainty usually translates into a slower maturation process, which Bohn (2005) modeled as a transition "from art to science", (Bohn, 2005). This transition involves a progressive decrease in technological uncertainty, which happens mostly during a period where a few individuals know how to make the technology work but a lack of scientific understanding of why it works hinders the codification of their knowledge and the adoption by other players (Bohn, 2005; Bonnín Roca et al., 2017; de Solla Price, 1984).

Material and process intensive products often require significant capital investment and can involve significant time to reliably achieve a desired outcome, if at all. Such a lack of reliability can be a deterrent in the diffusion of emerging technologies, as the initial investment might be seen as a 'sunk cost' (Hall, 2004; O'Brien and Folta, 2009). In addition, the evolution of the incumbent technology or other competing technology options can make the emerging technology less attractive (Arthur, 1989; Fuchs and Kirchain, 2010; Rosenberg, 1972), at least in the short term (Chari and Hopenhayn, 1991), especially when network externalities are important (Fontana, 2008; Katz and Shapiro, 1986; Shapiro and Varian, 1999). As a consequence of these risks, firms and venture capitalists can be reluctant to invest (Department of Energy, 1989). This reluctance might be exacerbated in the case of small firms, which typically face greater financial constraints (Gallego et al., 2015; Kaufmann and Tödtling, 2002; Madrid-Guijarro et al., 2009; Oakey, 1990), or in industries where risk-aversion is high due to the potential for large social losses (Downer, 2017; Slovic, 1987). Some of the above-described risks might be ameliorated if firms can experiment with the technology and exchange knowledge with other players (Gnyawali and Park, 2009; Rogers, 2003), have enough resources to invest in a diversified R\&D portfolio, (Kirchhoff et al., 2001), or establish corporate strategies to balance exploration and exploitation activities (Cegarra-Sánchez et al., 2020). In addition, the emergence of complementary technologies such as powerful computer simulation techniques may encourage experimentation by lowering the time and capital required to perform R\&D (Dresselhaus and Thomas, 2001; Thomke et al., 1998; Thomke, 1998). A question not answered by existing innovation studies is how the diffusion of technologies that exhibit one or more of the above-described challenging characteristics might be affected by external shocks.

\subsection{The role of public support in technology diffusion}

Public institutions may serve to accelerate diffusion of an emerging technology, for instance through institutions to coordinate the 
generation and exchange of knowledge (Lynn et al., 1996), and the allocation of public funds to support private R\&D efforts (Lerner, 1996; Martin and Scott, 2000). A diverse pool of actors is involved in technology diffusion, such as firms, users, universities, non-university research organizations, standards committees, venture capitalists, and others (Bergek et al., 2008a). Overall, geographical proximity among researchers may create opportunities for pooling resources, including expensive capital, and creating knowledge spillovers across firms (Asheim and Isaksen, 1997; Clark, 1984; Cooke, 2001; Gertler, 1995; Munari et al., 2012). However, while geographical concentration might increase interactive learning, excessive geographical concentration might also lead to situations of technology lock-in (Boschma, 2005).

The involvement and roles of these actors as well as the most effective framework to foster technology adoption will vary across different nations, industrial landscapes, and cultures (Fagerberg and Godinho, 2005; Furman and Hayes, 2004; Malerba and Nelson, 2011; Zeitlin and Herrigel, 2000). In studying the institutions supporting innovation, different scholars have focused on different units of analysis: national institutions for creating and supporting innovations (Nelson, 1993), the distinctive policy and interfirm linkages associated with a region (Cooke et al, 1997; Malerba, 2002), and institutional complementarities that occur as regional and national (Helveston et al., 2016) or supranational (such as the European Union) (Cooke, 1992; Morgan, 2007) policies interact. Given the blurry geographical boundaries of the institutions supporting technology diffusion, some scholars have put the technology itself at the center of the analysis (Bergek et al., 2008a; Carlsson and Stankiewicz, 1991). However, existing work is limited to the evaluation of the fitness of a given system for the diffusion of a technology (Asheim and Coenen, 2005; Bergek et al, 2008a; Fagerberg and Srholec, 2008; Freeman, 2002; Hekkert et al., 2007; Nelson, 1993), and offers little insights into how the supporting system may need to differ depending on the characteristics of a certain technology.

Governments have many mechanisms by which to provide firms and the research community with additional funding and channels for the acquisition of know-how (Breznitz, 2007; Cohen and Noll, 2002). Policy can include the creation of infrastructure to generate knowledge, developing incentives to guide industry's efforts, and constructing institutional frameworks to shape policy-making and firms' strategies (Armanios et al., 2017; Veloso and Soto, 2001). Such policies may reshape technological directions and form new networks of actors to foster the creation of markets (Bergek et al., 2008b). For instance, Israel grew strong IT and life sciences industries by creating a large venture capital pool with advantages for foreign investors, and allowing public companies to be dual listed in the Tel Aviv and New York stock exchanges (Wonglimpiyarat, 2016). Ireland sought to promote foreign direct investment in the manufacturing sector by first issuing long-term tax holidays, and later substituting these for low corporate tax rates (Buckley and Ruane, 2006). Taiwan sought to transition to high-tech industries through the creation of a large state-backed enterprise, TSMC, which subsequently became the world leading foundry for semiconductors (Amsden and Chu, 2003); and created science parks where companies enjoy substantial financial benefits, with the goal of attracting foreign entrepreneurs (Yang et al., 2009). Policies might be different for each country, but all success cases share the need for flexible institutions to accommodate for rapid technological change (Amsden and Chu, 2003; Breznitz, 2007; Lee, 2005).

Changes in policy, while sometimes needed, may exacerbate uncertainty surrounding the returns to investment in emerging technologies (Aldrich and Fiol, 1994), undermining both domestic (Ferraz and Kupfer, 1999) and foreign (Bevan et al., 2004) private investment. Firms tend to resist change when institutions have a low social legitimacy (Oliver, 1991), or are perceived as transient. In the words of North and Weingast (1989), government needs to make a 'credible commitment.' For instance, the successful introduction of locally-manufactured wind power in Inner Mongolia enjoyed institutional support for twenty years (Leary et al., 2012). In the USA, the Obama administration created a
National Network for Manufacturing Innovation, to be developed over ten years but funded through a one-time infusion, thereby assuring the continuity of the project until the new organizations are financially self-sustainable (Sargent, 2012). Conversely, long-term developments in industries which require a heavy investment in infrastructure such as renewable energy (Mowery et al., 2010; Narayanamurti et al., 2011; Schuelke-Leech, 2014), or telecommunications technologies (Glimstedt, 2001; Henisz and Zelner, 2001) have been hampered by risky or unpredictable institutional environments (Henisz, 2002). Unstable R\&D funding might be especially harmful in technology fields which depend heavily on long-term basic research, such as healthcare or biotechnology (Freeman and van Reenen, 2008; Hopkins et al., 2013; Oakey, 1990). Sudden institutional instability can be caused by a number of factors, including macroeconomic instability which obliges institutions to adapt to a new and changing financial landscape (Godinho and Mamede, 2016; Goldstein and Bergsten, 1998; Mazzucato, 2013; Perez, 2010). The rise of domestic tensions in the absence of major external threats may blunt government's interest in promoting innovation (Taylor, 2016). During periods of crisis, such as the Great Recession, the public R\&D budget may decrease (Sanz-Menéndez and Cruz-Castro, 2003).

In technology adoption, "history matters" (Maskell and Malmberg, 1999), and, especially in the early stage in the introduction of a technology, even "small events" may decide whether a technology is locked in or locked out (Arthur, 1989). Without the proper sponsorship, an emerging technology which is technically superior might be locked out if standards fail to meet industry's expectations or the timing of adoption is inadequate (too early or too late) (Schilling, 1998). Volatility in R\&D funding may hinder long-term research (Schuelke-Leech, 2014) and especially affect the pipeline of early career researchers (Freeman and van Reenen, 2008). The availability of venture capital may also decrease (Paik and Woo, 2014), industry exit rates may increase (Anderson and Tushman, 2001)and startups may experience higher failure rates during periods of recession (Geroski and Gregg, 1997). In some cases, public intervention may be needed throughout the maturation process (Cohen and Noll, 2002; Lerner, 1996; Martin and Scott, 2000).

Our paper contributes to the literature by adopting a different perspective about the relationship between institutional stability (or the lack thereof) and the adoption of an emerging technology. We do not ask how institutional changes may affect the introduction of a technology, but what characteristics of the technology may make it more resilient to changes in the institutional landscape. In addition, studies regarding the effect of institutional support in adoption have largely focused on infrastructure technologies. Our study purposely focuses on the extreme case of the adoption of two technologies both based on process innovations, whose extreme nature we believe particularly instructive in generating new insights for theory.

\section{Institutional promotion of additive manufacturing technologies}

Additive manufacturing (AM), also known as 3D-printing, involves a family of diverse manufacturing technologies which allow the user to build an object layer-by-layer from a digital design. Some of AM's advantages, as compared to traditional manufacturing technologies, include the ability to create very complex geometries, reduction of material waste, and in some cases, reduction in time-to-market (Harris, 2011). Some authors have also claimed that these technologies may change the optimal supply chain configuration, making localized production of some parts more desirable (Gebler et al., 2014; Petrick and Simpson, 2013). Overall, AM is portrayed as a disruptive technology (Gartner and Fink, 2018; Maresch and Gartner, 2020).

Early developments in AM took place during the 1960s and 1970s, led by the Battelle Memorial Institute in the USA, which used materials developed by DuPont, and benefitted from DARPA funding (Wohlers, 2005). What most consider to be the first prototype AM machine - able to cure photopolymers in a similar process to current stereolithography 
(SLA) equipment - was invented in 1980 in Japan by the researcher Hideo Kodama, at the Nagoya Municipal Industrial Research Center (Wohlers, 2005). In Europe, French researchers working for the Cilas Alcatel Industrial Company filed a patent of an AM machine which used a single laser as a heat source (Wohlers, 2005). In 1987 the first SLA machine was commercialized by the American company 3D Systems, and a number of Japanese and European competitors joined the market in the early 1990s (Wohlers and Gornet, 2016). Selective laser sintering (SLS) machines were commercialized first by the American company, DTM, in 1992 (Wohlers and Gornet, 2016), and in 1994, the German company, EOS, presented the first prototype of their Direct Metal Laser Sintering (DMLS) machine, commercialized in 1995 (EOS, 2017).

In its early stages, AM technology was primarily used to more rapidly build prototypes and thus accelerate the development of new products (Yan and Gu, 1996). As the technology matured, improvements in speed, dimensional accuracy and the development of new materials made rapid prototyping technologies progressively more suitable for the production of final parts (Gibson et al., 2010). Currently, AM is being integrated with other pillars of the Fourth Industrial Revolution such as the Internet of Things (Tolfree and Walsh, 2018). We distinguish between polymer additive manufacturing (PAM) and metal additive manufacturing (MAM) because of significant differences in the underlying science, industrial applications, market stakeholders, and level of maturity of the two technologies.

High-income regions such as United States, China, Singapore and the European Union have been devoting hundreds of millions of dollars to develop and promote additive manufacturing technologies (Ghobadian et al., 2020; Santos et al., 2017). Countries at the technological frontier perceive AM technology as providing an opportunity to revitalize their national manufacturing industry and decrease their dependency on foreign countries for parts. In the current framework program, the European Union considers AM as a 'Key Enabling Technology'. In the United States, the Obama Administration launched, in 2012, the National Additive Manufacturing Innovation Institute, currently known as America Makes, to revitalize American manufacturing. In China MAM is seen as offering a chance to leapfrog some of their missing capabilities in the manufacturing, and simplify logistics (Li, 2018). There is also interest in MAM in developing countries such as South Africa (Alabi et al, 2019), which has invested highly in MAM since 1994 and plans to increase their investment to promote activities in the biomedical and aerospace sectors (Wohlers Associates, 2016). PAM also holds promise to potentially revolutionize a variety of fields. For instance, in biotechnology PAM could be used to print organic tissues and even entire organs (Abdollahi et al., 2019; Sun et al., 2020). In industries where lightweighting provides important financial benefits such as aerospace applications, high performance polymers, including high-performance composite materials (Qiao et al., 2019), can be used to replace metallic structures. PAM can also be used in traditional industries such as shoemaking to produced customized, high-performance soles (Shahrubudin et al., 2019).

However, there are also reasons for countries not to invest in additive manufacturing technologies, especially in situations of resource scarcity. In recent years there has been increased criticism of the mainstream view that $\mathrm{AM}$ is going to revolutionize global manufacturing. These critics argue that AM is overvalued and is only going to change the industrial landscape dramatically in cases where customization plays an important role, or geometrical complexity has an important influence in the lightweighting and overall cost-performance of components (Baumers and Holweg, 2019; Bonnín Roca et al., 2019).

\section{Methods}

We use a longitudinal comparative two-case study (Eisenhardt, 1989; Yin, 2013) methodology to analyze the diffusion of PAM and MAM in Portugal within the Portuguese molds industry, and the challenges to each technology's further adoption at firms. Our analysis spans approximately 25 years, from the early adoption of PAM technologies in the 1990s up through the end of 2016. We triangulate 44 interviews, 75 hours of participant observations and archival data (Jick, 1979).

Our unit of analysis is the technology itself. We start by providing an analysis of the sources of market and technological risks which may affect firms' adoption decisions. We examine differences in capital requirements and operating costs between PAM and MAM, and we discuss differences in the technical and production environment which may affected the perceived profitability of both technologies. ${ }^{1}$ Given the path-dependent nature of technology adoption (Maskell and Malmberg, 1999; Patel and Pavitt, 1994; Teece and Pisano, 1994), we continue our analysis by reconstructing the history of PAM and MAM in Portugal, emphasizing the stability, or lack thereof, in the actors and institutions that played key roles in supporting the diffusion of the technologies in the country. We finish with an analysis of how sudden changes in funding policies at the regional, national and supranational levels may have affected MAM more than PAM. Based on our findings, we generate propositions about why some technologies might be more resilient to institutional instability than others.

\subsection{Data sources}

We selected our 45 interviews (see Appendix) to cover a broad range of stakeholders including firms in different sectors, technology centers and research organizations, to contrast different perspectives about the challenges in the adoption of MAM technology. Our first interviewees were selected based on the list of attendants to "Portugal3D", a private initiative to bring together all the relevant players with experience in the use of additive manufacturing in the country (Portugal3D, 2015, p. 3). This first group of interviews and visits to factories helped us better understand the types of PAM and MAM applications that are attractive to Portuguese industry, and the existing conditions in terms of capital and know-how available.

After a first round of contact, we snowball-sampled (Denzin and Lincoln, 2011) our next interviewees, and extended our sample to sectors such as aeronautics or automotive which were not present at the Portugal3D event but represent two of the main markets for MAM (Wohlers Associates, 2016). This second group of interviews helped clarify why many companies might be interested in the technology, but have not yet purchased equipment.

With the objective of analyzing the path-dependency of both PAM and MAM, and reconstructing the history of both technologies in Portugal, we also sought out people who have been working with both technologies in the country for over twenty years. We complemented their oral history interviews with publicly available data from Portuguese and European funding agencies and other publications from research organizations.

We complement our 45 interviews with archival data (Table 1). We divide our archival data sources into different types: macroeconomic data; history of Portuguese institutions; history of PAM, MAM and their market applications; technical documents about PAM and MAM; and history of PAM and MAM in Portugal.

In addition, we conducted approximately 75 hours of participant observations. These included: 23 visits to AM manufacturing and research facilities, to observe and understand the conditions and

\footnotetext{
1 Our paper focuses on comparing why two emerging technologies (PAM and MAM) experiencing the same institutional context (Portugal between 1990 and 2016) develop differently. While we do not focus on AM globally, as the global context will inevitably influence the Portuguese organizations, we include in section 3 a history of additive manufacturing globally and, in section 4.1, where the Portuguese context fits in. Likewise, certain changes experienced by the firms in our paper happen due to the developments outside Portugal. For example, the decrease in machine price experienced by the Portuguese firms in our paper, takes place at a global scale.
} 
Table 1

Summary of archival data sources used in this paper. Full references can be found in the "Referenced data sources" section at the end of the paper.

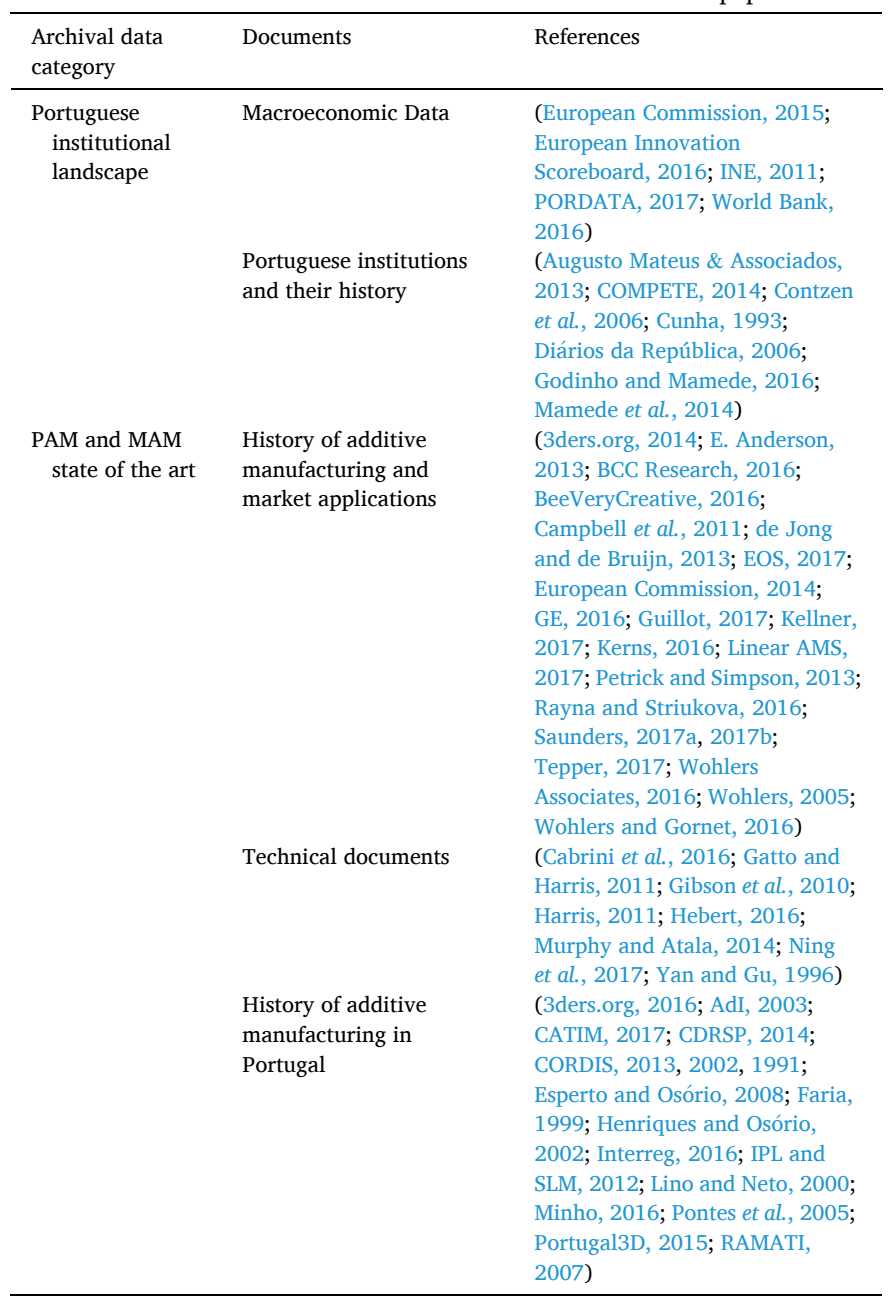

restrictions of the Portuguese industry; plus attendance at conferences and attendance at fairs and public forums where the applications of additive manufacturing technologies were discussed. In addition, we attended a day-long workshop organized by the Portuguese Minister of Science where high-level public officials and managers of Portuguese research institutions discussed the health and needs of the Portuguese innovation system.

\subsection{Case selection: Portugal and the Portuguese molds industry}

Portugal is the westernmost country in continental Europe, and has a population of approximately 10.5 million people (INE, 2011). From 1933 until 1974 Portugal was a dictatorship, which isolated the country from the European integration process after World War II (Royo and Christopher Manuel, 2003) and resulted in a serious lag in education due to the opposition by elites to the modernization of the educational system (Cunha, 1993). The effects of this structural lag can still be felt. According to the European Innovation Scoreboard (European Innovation Scoreboard, 2016), Portugal ranks 24th out of 28 in terms of completion of tertiary education in the European Union. This lack of individuals with tertiary education likely constrains the human resources available to invent and adopt advanced technologies.

In 1986, Portugal joined the European Community (Lochery, 2017). Between 1986 and 1992, FDI represented an annual contribution of 3\% of its GDP, directed mostly towards the manufacturing sector (Guimarães et al., 2000). In 1999, Portugal joined the Eurozone. In association with its entry into the Eurozone and global events such as the entry of China into the World Trade Organization (WTO), Portugal's competitiveness as a manufacturing location and as a destination for FDI diminished (Mamede et al., 2014). The state's ability to invest in education and R\&D was further diminished by the 2009-2010 financial crisis, which saw Portugal's debt soar to $130 \%$ of GDP. (World Bank, 2016).

Manufacturing value added from medium and high-tech manufacturing in Portugal is below the European average $(12 \%$ in Europe vs 5\% in Portugal). An industry that has somewhat bucked this trend is molds manufacturing industry (here, metal molds for plastic parts). This is a highly export-oriented industry: $85 \%$ of output is exported (CEFAMOL, 2016). Portugal ranked eighth in terms of exports of metal molds in 2015, and was the country in the world with the highest 'revealed comparative advantage' (RCA). ${ }^{2}$ (Balassa, 1965; Laursen, 2015)

The molds industry has been an early adopter of both PAM and MAM in Portugal. While PAM was initially used to build prototypes of molds, MAM holds the potential to incorporate complex internal cooling channels in molds. Such complex cooling channels could reduce the time required to produce each part, increasing the productivity of each mold. Nonetheless, producing molds using MAM presents several challenges such as higher porosity, less resistence to fatigue, lower corrosion resistance, and lower thermal conductivity, among others. Overcoming these potential disadvantages to MAM-manufactured mold performance require $R \& D$ and precise control of the MAM manufacturing process.

Despite its potential benefits, the level of introduction of MAM technology is low across the Portuguese molds sector, and more generally across the country. In contrast, countries which are direct competitors in the mold-making industry, such as China, United States and Germany, are investing hundreds of millions of dollars in the promotion of MAM (European Commission, 2014). Given the potential benefits of the technology, Portugal may risk losing its competitive advantage in mold manufacturing if it does not successfully adopt metal additive manufacturing.

In contrast to MAM, Portugal, and in particular its mold industry, successfully adopted PAM. In this paper we ask why Portugal has lagged in the adoption of MAM, even though such adoption is important to the industry's continued success. To better understand why the molds industry adapted and invested in PAM but not (MAM), we investigate in parallel differences in the technologies and the institutional environments that prevailed in Portugal as the technologies matured.

\section{Findings}

\subsection{Technical differences between PAM and MAM}

While a variety of factors may affect determine technology diffusion (Hall, 2004; Mansfield, 1961; Rosenberg, 1972), technology diffusion may be particularly challenging in cases where technical complexity, and thus technological uncertainty, is very high (Rogers, 2003; Tornatzky and Klein, 1982). We next analyze the most relevant technical differences between PAM and MAM, and how, based on those differences, PAM might experience faster rate of diffusion than MAM.

PAM and MAM are process-based technologies, this is, technologies where a slight change in the manufacturing conditions may lead to a large change in the final properties of the manufactured component (Linton and Walsh, 2008). Process-based technologies are also often characterized by having a large number of sources of uncertainty which can slow their maturation rate (Bonnín Roca et al., 2017). We use Bonnin Roca et al's (2017b) framework to analyze the differences in the sources

\footnotetext{
${ }^{2}$ The RCA is equal to the share of the country's exports of a certain product divided by the share of world exports of that same product. If RCA is above 1, it is said that the country is specialized in that particular product (Laursen, 2015).
} 
of technological uncertainty between PAM and MAM across four dimensions: complexity of the technology, measured through the number of constituents; the need for novel measurement techniques; the testability across intermediate stages of production; and the importance of 'learning by using' (Table 2).

In terms of complexity of the technology, measured through the number of constituents, both PAM and MAM are subject to variability in the composition and morphology of the material input, the configuration used in the machines, and the type of post-processing applied. However, melting metal requires operating with much higher temperatures than melting polymers. This creates two additional technical problems: the difference in temperature between the molten and unmolten material is higher, increasing the chances of obtaining undesired microstructures (Frazier, 2014); and metals require specific atmospheric control to avoid contamination and corrosion at high temperatures (Hebert, 2016).

The second and third dimensions are related to testing, and the need for testing depends on the type of component being made. In applications where structural integrity is important, both PAM and MAM need the development of better measurement techniques (Gatto and Harris, 2011; Mani et al., 2015). In the case of MAM, mold inserts need to withstand cyclical loads, and quality control is critical. Early applications of PAM in the field of rapid prototyping did not have to withstand such mechanical loads.

Finally, learning by using plays a more important role in metals than in polymers. Metals face problems such as fatigue and corrosion, which only appear after a component has gone through a large number of cycles. MAM materials are particularly sensitive to this issues due to components' porosity (Cabrini et al., 2016; Frazier, 2014). Both fatigue and corrosion are critical problems to avoid in the molds industry, given that the process of injection molding implies working with highly corrosive polymer at high temperature, for hundreds of thousands or even millions of cycles. A technical manager explained: "The powder I found was nothing close to the inox steel we want, like AISI 304 L, 306 L, 2083 or 2085. There are two main issues with current materials: lower resistance to corrosion, which is very important because some of the polymers they inject are very corrosive; and much lower hardness" (Interview 1). PAM materials do not experiment these issues and therefore there is less room for uncertainty regarding the final performance of the product: "Polymeric AM is much easier to work with, cheaper, faster, and has more detail. It is a perfect solution for all the prototyping we have to do" (Interview 1).

In addition to the intrinsic technical differences between PAM and MAM, PAM has also benefitted from broader dispersion of knowledge related to at least lower-end applications of the technology. Nowadays there is abundant PAM training material online from the maker community, which serves as a good starting point (Interviews $3,11,24,25$ ). In addition, training is available by PAM equipment and software suppliers (Interview 3,10). In the case of MAM, the lack of widely available, reliable training is problematic as firms "only buy a technology if the equipment supplier can also come to the center and train the employees. Universities don't supply the skills required to work with these technologies." (Interview 3). Thus, from the point of view of the number of potential applications (Gross, 2017), PAM should experience higher diffusion

Table 2

From a technical perspective, MAM is subject to a larger uncertainty than PAM.

\begin{tabular}{|c|c|c|}
\hline Sources of uncertainty & PAM & MAM \\
\hline Number of constituents & Lower & $\begin{array}{l}\text { Higher, due to } \\
\text { additional process } \\
\text { control }\end{array}$ \\
\hline $\begin{array}{l}\text { New measurement techniques } \\
\text { required }\end{array}$ & $\begin{array}{l}\text { Yes, but not necessary } \\
\text { for prototypes }\end{array}$ & Yes \\
\hline $\begin{array}{l}\text { Testability during } \\
\text { intermediate phases of } \\
\text { production }\end{array}$ & $\begin{array}{l}\text { Not yet, but not } \\
\text { critical for prototypes }\end{array}$ & Not yet \\
\hline Learning by using & Lower & Higher \\
\hline
\end{tabular}

rates than MAM.

Furthermore, there are important differences in the incumbent technologies between PAM and MAM. PAM replaced costly, slower and unreliable handcrafted prototyping techniques. However, MAM replaced faster and more reliable machining technologies. Hence, the perceived benefits of the technology relative to its incumbent might be higher for MAM than for PAM.

In summary, MAM today is a less mature technology than PAM (e.g. per the art to science definitions in Bohn, 2005). Even at the technological frontier, engineers are not yet able to define in equations the relationship between process inputs and technological outputs. This greater uncertainty in MAM may have two implications. First, firms willing to work with MAM need to spend a larger amount of resources in R\&D and training, which Portuguese SMEs may not have. Second, we would expect this increased uncertainty to increase the risk aversion of firms towards MAM more than towards PAM, and that the learning period for an industry to make effective use of MAM might be longer. This risk aversion is also affected by the relative advantages of the technologies with respect to their incumbents.

\subsection{Institutional support for the diffusion of PAM and MAM in Portugal}

\subsubsection{Actors, networks and timeline}

Existing institutions may affect technology diffusion by helping modify actors' behavior (DiMaggio and Powell, 1983, 1983; Hall, 2004; Nelson, 1982; Rogers, 2003; Rosenberg, 1972). Government may also play a role in creating organizations and networks to coordinate efforts in creating new knowledge (Lynn et al., 1996), which might be different across regions and industrial sectors (Cooke et al., 1997; Malerba, 2002). At the same time, institutional complementarities (Helveston et al, 2016) can lead to intended or unintended interactions between these regional policies and policies by supranational entities such as the European Union (Cooke, 1992; Morgan, 2007). We examine the histories of PAM and MAM in Portugal with the objective of identifying the main actors in charge of diffusing both technologies, and how their actions might have been influenced by a changing institutional landscape.

5.2.1.1. Polymer AM. The history of PAM in Portugal began in 1990, only 3 years after the commercialization of the first stereolithography (SLA) machines (Wohlers, 2005), when researchers from the Instituto Superior Técnico (IST) in Lisbon joined the INSTANTCAM project, a European consortium led by Danish researchers and funded under the EU's second Framework Program (CORDIS, 1991). INSTANTCAM studied the processes of stereolithography, solid ground curing, selective laser sintering (SLS, commercialized in 1992) and laminated object manufacturing (LOM), using a variety of polymers (Dolenc, 1994).

In 1992 Portugal acquired their first SLA machine, which was set up at ITEC, a research institute in Lisbon (Lino and Neto, 2000). Work continued between 1994 and 1998 under the project PROTOTYPING, funded by NATO's "Science for Stability" program. The project's aim was introducing PAM in the manufacturing chain of the foundry industry (Faria, 1999). PROTOTYPING was led again by IST in Lisbon, but included two firms and a training center from the North of the country (Faria, 1999).

In 1997, the National Network of Rapid Prototyping (Rede Nacional de Prototipagem Rápida, or RNPR, was created using EU funds (Henriques and Osório, 2002). The RNPR was the cornerstone of the introduction of polymer AM technologies in Portugal, given that it was a horizontal project encompassing companies in design, molds and foundry processes; four different research institutions; and the technology center for the molds industry (CENTIMFE) (Henriques and Osório, 2002). The project, which lasted until 2000, and brought together players from all across the country, not just from Lisbon but also from the cities of Porto, Braga, Évora and Leiria; and bridging the gap with industry. New equipment was bought to complement the 
existing SLA equipment in Lisbon: LOM at a research center in Porto, and SLS at CENTIMFE, in Leiria (Henriques and Osório, 2002). The resulting access to equipment with a broad range of capabilities allowed researchers to analyze the tradeoffs and possibilities across different material and equipment systems. During this period, Portugal joined RAPTIA, a European project constituted by 26 organizations for the promotion of rapid prototyping in both polymers and metals (CORDIS, 2002). By the end of the year 2000, nine polymer machines had been installed in the country, including five in the private sector (Lino and Neto, 2000).

In 1999, ITEC went bankrupt but a subgroup inside the research organization created a spin-off called Agiltec (Interview 7), which became a technology transfer center for efficient production technologies. The SLA machine was transferred to Agiltec, whose employees kept working inside RNPR and other projects related to PAM and MAM (Interviews 7,8). In 2005, Agiltec had to close as well due to financial difficulties (Interview 7).

After the end of the RNPR project, the development of PAM was led by CENTIMFE, which has since then participated in 12 different projects related to PAM, 6 of them at the European level (CENTIMFE, 2016). Between 2002 and 2005, the project Rapid Tooling (Fabrico Rápido de Ferramentas, or FRF) continued the work started during RNPR (AdI, 2003). In parallel, two other projects called Protomolde (1999-2001) and Hibridmolde (2002-2005), led by the molds company Moliporex and with the support of CENTIMFE, the University of Minho and the Polytechnic of Leiria (IPL), explored further applications of PAM in the molds sector (Pontes et al., 2005).

In 2007, a new boost was given to PAM through the creation of the center for Rapid and Sustainable Product Development (CDRSP) at IPL. ${ }^{3}$ CDRSP was located in Leiria due to its closeness to the mold making companies, which were the main users of PAM technology in the country (Interviews 7,9). Since the creation of CDRSP, PAM research in the country has shifted towards higher-end and more technically challenging applications, especially in the development of biocompatible polymers and tissue engineering (CDRSP, 2014). Most of these projects are in collaboration with the University of Coimbra and with the leading molds companies.

As of September 2016, there were at least a hundred industry-graded PAM machines in the country (Interview 10). In addition, every technical university has PAM equipment (usually desktop machines), which students can use to become familiar with the technology (Interviews 9,10,11,12,13). In 2011, Portugal's first manufacturer of desktop 3D printers, BeeVeryCreative, was founded at the University of Aveiro. BeeVeryCreative participates in research projects with local companies and the university to develop new materials for their printers (Interview 14).

The development of PAM in Portugal suffered some major setbacks such as the 1999 closure of ITEC, which first brought SLA technology to the country, the closure of Agiltec, and the end of nationwide research consortiums. Nevertheless, the country was able to transition from less sophisticated applications in the area of prototyping in the foundry and molds industries, to becoming a reference center in the area of biopolymers and achieving high visibility in PAM at universities and other higher education institutions (Fig. 1). Private actors took leadership in the adoption of PAM in traditional sectors. As we will see below, the same levels of adoption have not occurred for MAM.

5.2.1.2. Metal AM. The first contact of Portuguese researchers with MAM was during the PROTOTYPING project funded by NATO in 1994. As part of the project, one (out of 38) prototypes made for the foundry industry was made using a Direct Metal Laser Sintering (DMLS) machine - a machine only first commercialized in 1995 - in France (Faria, 1999).

\footnotetext{
${ }^{3}$ As a polytechnic, IPL offers a more professionally-oriented education than universities, and cannot offer $\mathrm{PhD}$ diplomas.
}

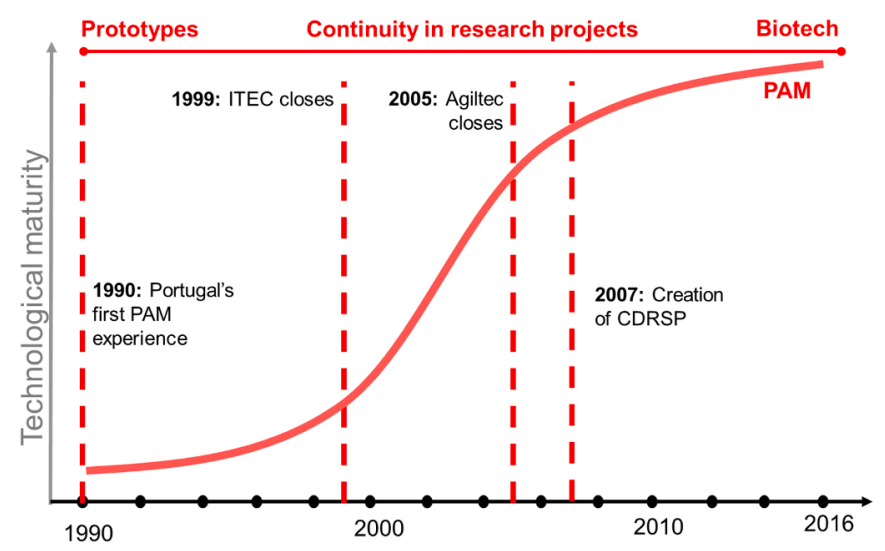

Fig. 1. Despite some setbacks in institutional support, PAM evolved from lowtech applications such as prototypes, to high-tech applications such as biotech.

In a final report industry suggests it was satisfied with the results from the PAM prototypes, however, for the MAM prototype, accuracy was "not [good] enough for sand casting" (Faria, 1999).

Despite this initial challenge, Portugal bought a DMLS machine within the context of the National Network of Rapid Prototyping (RNPR) to explore not only polymer technologies but also metals for rapid tooling applications. The metal machine was installed in Lisbon at INETI, the National Laboratory for Engineering, Technology and Innovation (Interviews 7,8).

Soon after, in the period 1999-2003, INETI joined RAPTIA. In 2003, INETI supplied their DMLS machine for the Rapid Tooling (FRF) project, a follow-up of RNPR. Although the technology was still rudimentary ("we had to spend more time polishing the pieces - which at that time we did manually - than building them"), experts considered the results satisfactory (Interview 8), which suggested the possibility of cost competitiveness of MAM against traditional manufacturing processes in the molds sector (Esperto and Osório, 2008). Between 2004 and 2007, INESC INOV, a research institute in Lisbon, led a European project to study MAM titanium implants (RAMATI, 2007).

Institutional set-backs started in 2005. First, Agiltec, the technology transfer office whose staff had also been working with the machine at INETI and had studied the properties of the parts manufactured by DMLS, was closed due to ongoing problems securing funding. Then INETI closed operations in 2006, following the recommendations of an international working group created to assess the state of the Portuguese system of national laboratories (Contzen et al, 2006; Diários da República, 2006). Thus, within months of each other, the two leading research institutions in MAM, both located in Lisbon, had been shut down. With that move, the creation of new MAM-related know-how at research institutions ceased in the country. Meanwhile, a Portuguese machine manufacturing company ${ }^{4}$ played a secondary role in the European project IMPALA, a project for developing MAM applications for high-tech industries such as aeronautics or biomedical (CORDIS, 2013).

In December of 2012, a DMLS machine was bought at a research institution in Portugal (IPL and SLM, 2012). This DMLS machine was purchased by the center for Rapid and Sustainable Product Development (CDRSP), located within the Marinha Grande molds cluster. The purchase ended a six-year gap in MAM research at Portuguese research institutions (Fig. 2). By this stage, companies in the mold cluster of Marinha Grande had started acquiring their own MAM equipment and experimenting (with mixed results), but without relevant institutional support (Interviews 5,15,16).

Until November 2016, the machine at CDRSP was the only

\footnotetext{
${ }^{4}$ One executive of one of this companies had worked at Agiltec (2002-2003) and done research for FRF.
} 


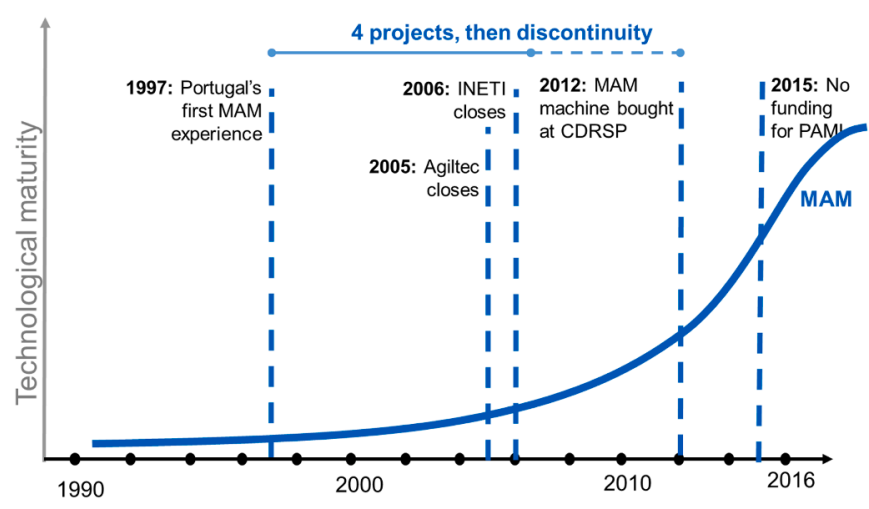

Fig. 2. MAM research suffered from discontinuities at an early stage of maturation.

operational MAM machine at a Portuguese research institution. Unfortunately, two years after its acquisition, and shortly after the warranty of the MAM machine expired, one of the lasers broke down. This breakdown translated into an additional four-month downtime (Participant Observation, May 5, 2016). Today, the machine is used to supply parts to other universities, which are conducting projects related to MAM, primarily in new material characterization (Interviews 9,11,17). The CDRSP has also received some criticism for not fully utilizing their machine (Interviews 15,16).

In recent years, there has been a new wave of interest towards MAM technology, but, in the case of MAM, the institutional instability caused by the 2009-2010 financial crisis may be creating extra roadblocks for researchers. In 2014, the Portuguese Science Foundation approved the creation of the Additive Manufacturing Initiative (PAMI), a research partnership between CDRSP, CENTIMFE and the University of Coimbra. This partnership has the potential to lead to additional use of the existing DMLS machine. However, PAMI's activities have to-date not started due to delay in the arrival of funding (Interview 18).

Corporate interest may also hold the potential to pave the way for MAM in Portugal, as happened in countries at the technological frontier. For instance, the German automaker Audi reported increases in performance (cycle time) of $20 \%$ in their molds with MAM components, and has recently partnered with the equipment manufacturer EOS to "transform the tool manufacturing industry" (Saunders, 2017a). In the USA, the mold-maker Linear AMS owns 17 MAM machines and has started to produce components for other industries such as biomedical and aeronautics (Linear AMS, 2017). In November 2016, a German manufacturing company, Bosch, opened a new research center in Portugal in collaboration with University of Minho. This center is focused on the development of advanced manufacturing techniques (including both PAM and MAM) for automotive applications (Minho, 2016). In June 2016, Addispace, a collaborative project between Portugal, Spain and France, was approved to evaluate the introduction of MAM in the aerospace sector (Interreg, 2016).

As of March 2017, we are aware of at least seven MAM machines in Portugal: two in molds companies, three in engineering companies born in the proximity of the molds cluster, and two in research centers. These numbers contrast with the overall pace of sales of MAM equipment worldwide, which presented an average growth rate of $30 \%$ between 2000 and 2015 (Wohlers Associates, 2016). Interestingly, none of the seven MAM machines in Portugal is owned by CENTIMFE, the technology center in charge of developing and disseminating new know-how in the molds industry, which was crucial in the implementation of PAM in the late 1990s and early 2000s ("In the $90 \mathrm{~s}$ there was a high expectation in the mold industry to manufacture critical parts with AM, but technology is not there yet", Interview 30). Outside the molds cluster, there is a growing interest in MAM in the Northern region of Porto, where the technology center for the metalworking industry (CATIM) has started a pilot educational project for 11 of their members
(CATIM, 2017) and a manufacturer of industrial equipment has developed a prototype of a MAM machine for the construction of large metal parts (3ders.org, 2016).

Most of the large molds firms in Portugal that produce MAM components outsource their production to local or foreign MAM shops (Interviews $1,3,4,16$ ). Due to the undersupply of skilled labor to work with MAM, the few local companies which have acquired MAM equipment are working very secretly so as not to reveal their internal knowhow, acquired through months of experimentation and exchanges with other MAM research centers around the globe (Interviews 5,15). This contrasts with the situation in other countries such as the U.S, Germany or the UK, where knowledge is at least to some extent being disseminated through public-private partnerships such as America Makes (The White House, 2012), and higher education institutions are already offering MAM-specific curricula (Guillot, 2017; Saunders, 2017b).

\subsubsection{Sudden changes in $R \& D$ funding}

A key factor in the diffusion of a technology is its perceived profitability (Hall, 2004; Rogers, 2003; Rosenberg, 1972) which is lower as the cost of acquiring equipment increases. For capital-intensive technologies, public support may help lower firms' risk aversion by providing $R \& D$ funds to acquire new equipment (Lerner, 1996; Martin and Scott, 2000). Here we analyze the changing initial investment to work with the two technologies, and whether there have been changes in the ease with which firms' could access capital. Our results show that, for a number of reasons, there have been changes in the availability of funding from regional, national, and European sources over the last two decades. These changes appear to have affected MAM more than PAM, due to the differences in the acquisition and subsequent marginal production cost of PAM and MAM equipment.

Currently, a MAM machine costs between half and one million euros (Laureijs et al., 2017), similar to the price of a high-end PAM machine. However, there is a much wider range of PAM machines available with an equivalently wide range of prices. Since 2009, low-end PAM machines can be acquired for less than $\$ 1000$ (Wohlers and Gornet, 2016). Today, these low-end machines can be acquired at Amazon.com for a couple of hundred dollars. There is also a difference in price of materials between MAM and PAM: One kilogram of steel powder for MAM may cost between one and two hundred euros, and titanium for MAM costs six or seven hundred euros per kilogram. On the contrary, a kilogram of polymers such as ABS or PLA for a desktop 3D printer costs only around 10 euros per kilogram (BeeVeryCreative, 2016). That said, high-quality resins and polymer powders cost several hundred euros per kilogram, similar to metals (Interviews 6,10).

The ability of Portuguese firms to make multi-million Euro investments is severely limited by their size. In 2012, there were about 450 companies in the Portuguese molds industry, half of which have 10 or fewer employees (Quadros de Pessoal). Only larger corporate groups may feel they have the scale to pool resources to invest in immature technologies, but they, too, can be limited in their ability to do so when their profit margins are low and volatile: "The mold sector is strong but they don't win much, they don't have much time to stop doing what they are and observe the market. And those who know about the technology, don't want to say it out loud because it is their advantage" (Interview 2).

This already limited ability worsened with the 2009-2010 financial crisis, during which Portugal experienced a dramatic increase in interest rates (Fig. 3). At this point in history, there were already low-end PAM printers in the market, three orders of magnitude cheaper than MAM printers. ${ }^{5}$ Hence companies did not necessarily have to borrow large

\footnotetext{
${ }^{5}$ Although high-end PAM machines have a similar price to MAM machines, our conversations suggest that, in the case of the molds industry, most applications do not need neither the quality nor the speed offered by such high-end equipment. (Interviews 10, 30)
} 


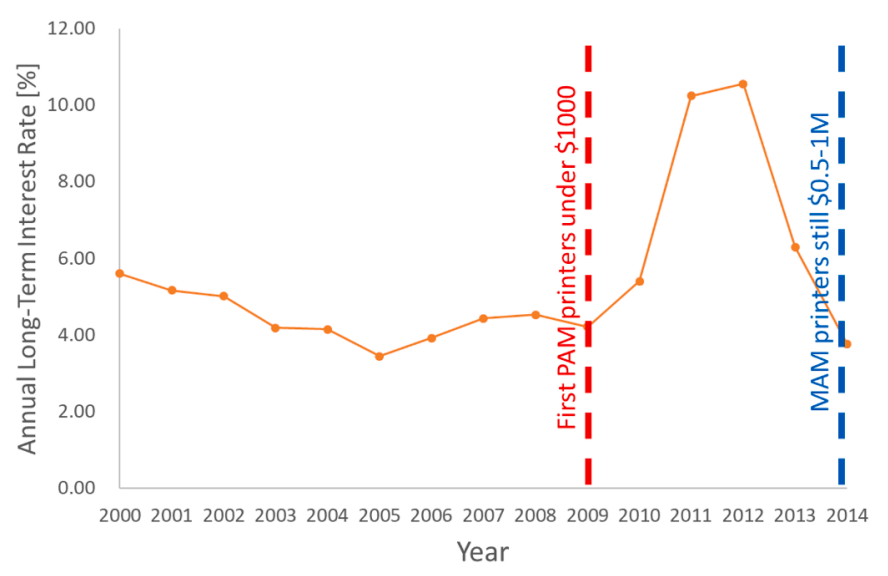

Fig. 3. The spike in interest rates might have affected PAM less than MAM. By the time interest rates rose, low-cost equipment was available for PAM but not for MAM. It is likely that firms that wanted to enter PAM could do so with lowcost machines, whereas firms that wanted to enter MAM were prevented from financing their purchases of the still-expensive MAM machines.

amounts of capital to become acquainted with PAM (although the cost of high-end machines is still similar for PAM and MAM).

The Portuguese molds sector has been able to recover from the crisis. However, our evidence suggests that while companies are generating profits again, they are focusing their innovative efforts in less risky, incremental improvements of their production process rather than working with immature technologies like MAM. As one engineer explains, "if you have to run the machine 20 times before you get the part right, the boss is not going to be happy" (Interview 5).

Proposition 1: Technology adoption may be more resilient to institutional instability in technologies that require lower capital investments.

Previous studies about the relevance of institutional stability in industries with high investment costs such as energy (Bergek et al., 2008b; Mowery et al, 2010) and semiconductors (Amsden and Chu, 2003; Lee, 2005) show that long-term institutional support is critical when capital requirements are high. Our findings are therefore in line with previous studies, but in the case of PAM and MAM the capital required is significantly lower than for cases like wind energy or semiconductors. Hence our case may help expand and generalize previous findings to lower capital investments than previously thought.

5.2.2.3. Instability in Portuguese $R \& D$ funding. To counteract limitations in their borrowing ability, firms may apply to traditional R\&D funds managed either by the Portuguese government or by the European Commission. However, those channels suffered instability during the same period interest rates spiked.

As in most European states (Makkonen, 2013), R\&D expenditures in Portugal fell during the crisis, from $1.58 \%$ of the GDP in 2009 to $1.28 \%$ in 2015 (World Bank, 2016). Due to the adverse macroeconomic conditions, there were not calls for new $R \& D$ projects in industry in either 2013 or 2014 (COMPETE, 2016). Portuguese Science Foundation (FCT) also suffered important delays in their payments, which affected a number of projects related to the introduction of PAM and MAM, including the Portuguese Additive Manufacturing Initiative (Interviews 18,23). A firm's manager complained to us: "the problem of Portuguese companies is that they don't want to spend their own money, they rely too heavily of public funds. Now Portugal 2020 is delayed after the government change, and industry projects are stopped as well" (Interview 10).

Portuguese R\&D funding is channeled through two different agencies: the Portuguese Science Foundation (FCT), under the Ministry of Science, Technology and Higher Education, and COMPETE, under the Ministry of Economy. R\&D funds from COMPETE come exclusively from the European Union (EU) through three different programs: the European Regional Development Fund (ERDF), the European Social Fund
(ESF) and the Cohesion Fund (CF) (COMPETE, 2014). Hence, COMPETE funds are subject to the conditions imposed by the European Union. EU Regions are classified into three groups: "more developed" regions (GDP per capita over $90 \%$ of the EU average); "transition" regions (GDP per capita between $75 \%$ and $90 \%$ of the EU average); and "less developed" regions (GDP per capita lower than $75 \%$ of the EU average) ("EUR-Lex 32013R1303," 2013). The amount of capital available, co-financing rates and the investment priorities differ depending on the nature of the region. For instance, about $50 \%$ of the funds are allocated for less developed regions and only $15 \%$ go to the most developed regions ("EUR-Lex - 32013R1303," 2013). Regulations establish a co-financing rate of $85 \%$ for less developed regions, $60 \%$ for transition regions, and $50 \%$ for the more developed regions ("EUR-Lex - 32013R1303," 2013).

When Portugal entered the European Union, all its regions fell within the less-developed category. However, as the Lisbon region reached the status of transition and later of more developed, investment started to phase out in the 2000-2006 program (Augusto Mateus \& Associados, 2013). While the region of Lisbon received about $30 \%$ of the structural funds in the 1994-1999 period, that percentage fell to only about $5 \%$ in the 2007-2013 program (Fig. 4).

The reduction of funding to the region of Lisbon might have affected MAM more than PAM. In 2006, MAM research was concentrated in Lisbon, while PAM research was much more mature and distributed across the country (CENTIMFE and CDRSP are located in the Centro region). Interestingly, this geographic concentration in Lisbon may have been associated with the immaturity of MAM in as much as engineers were required to work directly with the technology, and the concentration of such engineers and other expertise in the Lisbon region.

Proposition 2: Technology adoption may be more resilient to institutional instability in cases where the technology's activities are (geographically and/ or institutionally) disperse.

Previous studies suggest that in technologies with high levels of tacit knowledge like MAM, learning may only be able to happen at the location where the technology is used (Tyre and von Hippel, 1997). In addition, for these types of technologies, geographical proximity to experts can be crucial (Andersson and Ejermo, 2005; Mansfield and Lee, 1996; Maskell and Malmberg, 1999), including needing inventors, bench-level expertise, or design experts on the manufacturing line (Zucker and Darby, Pisano, Fuchs and Kirchain 2010). While subnational actors, including industrial clusters, may organize to protect their interests and shape the institutions that govern them (Hooghe, 1995; MacLeod Gordon, 2002) ${ }^{6}$ existing theory on the benefits of geographic concentration misses the tension between the need for proximity to accelerate the development of the technology, and an increased vulnerability that comes through such geographic concentration to changes in local institutions.

5.2.2.4. Instability in funding from the European Commission. Given the reduced availability of Portuguese R\&D funds, some Portuguese research organizations have tried to reduce their dependency on Portuguese R\&D funds and started to apply exclusively to EU (i.e. Horizon 2020) funds (Interviews 18,23).

However, several factors have also affected the availability of EU funds for Portuguese research institutions. First, the expansion of the European Union from 15 countries in 1995 to 28 countries in 2013 increased competition. Second, the conditions attached to these funds have changed. Under the 'Research for SME' program (2007-2013), projects required the participation of at least three different SMEs, from three different countries, and at least two different "Research and Technology Development" performers such as research centers or technology centers (European Commission, 2007). In the new

\footnotetext{
${ }^{6}$ A recent concrete example of such advocacy is Silicon Valley's lobbying to shape U.S. immigration policy to ensure that the pipeline of global talent on which it relies is not constricted (NPR, 2008; Younglai and Bohan, 2013).
} 

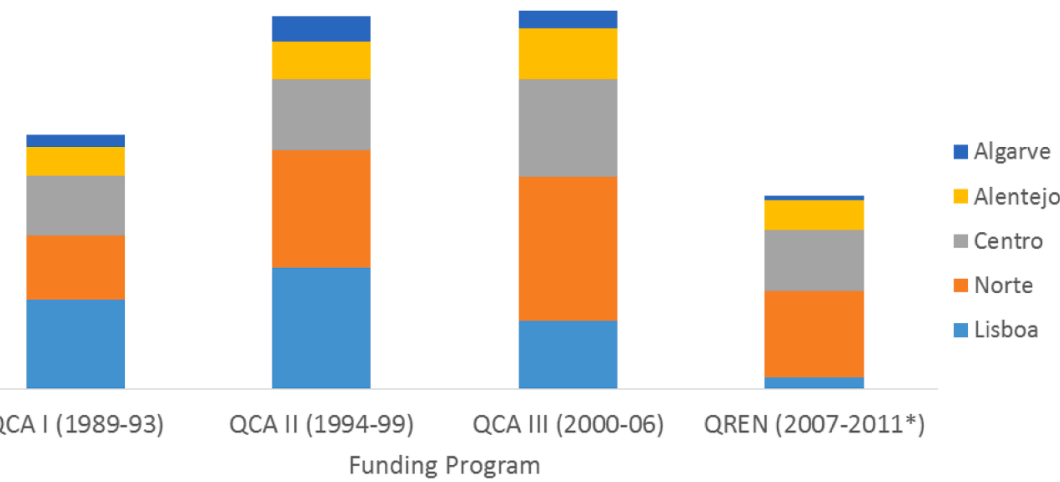

Fig. 4. Funding from the structural funds has reduced substantially, especially in the
framework program ended in 2013. Source: (Augusto Mateus \& Associados, 2013).

framework program (2014-2020), the "SME instrument" program is targeted towards "SMEs showing a strong ambition to develop, grow and internationalize", and any single European company can apply (European Commission, 2016). Thus, European funding for SMEs has shifted its focus away from encouraging research collaborations towards entrepreneurship and rapid growth companies seeking to internationalize. This shift decreases funding available for the Portuguese molds industry, which is characterized by small family businesses feeding a local industry. Research organizations struggle to adapt to these changes, in combination with other political factors: "The people at the organization changed every time there was a change in the government, the minister or the Secretary of State. In addition, funding schemes changed every time the EU Framework Programme changed" (Interview 23). Success rates for Portuguese projects fell from about 18\% in 2007-13 to about $13 \%$ in 2014 (European Commission, 2015). ${ }^{7}$

At the same time, with the shift of European funding programs towards entrepreneurship, PAM might have been slightly favored as it is increasingly used by the maker and startup communities to accelerate their product development (de Jong and de Bruijn, 2013; Rayna and Striukova, 2016). In contrast, MAM is predominantly used in components for traditional industries such as aeronautics, automotive or heavy machinery, which are not the focus of the 'Research for SME' program.

PAM not only appears to have received more funds than MAM, but it also has a larger initial market. Different consultant groups estimate that the present market for polymers is about five times larger than the market for metals (BCC Research, 2016; Wohlers Associates, 2016).

Proposition 3: Technology adoption may be more resilient to institutional instability in technologies with larger or more diverse markets.

Past studies show that firms are more likely to innovate when market sizes are larger (e.g. Acemoglu and Linn, 2004; Desmet and Parente, 2010) and that diffusion is faster when the range of applications increase (Gross, 2017). If markets are large or diverse enough, firms may pursue risky development programs even within an instable institutional framework.

\subsection{Interactions between technology maturity and institutional instability}

While both PAM and MAM technologies experienced Portugal's periods of institutional and financial instability, including instability in many of the same institutions, the institutional instability occurred at different points of each technology's maturation: PAM enjoyed a more stable institutional environment during the technology's early, immature stage, than MAM (Fig. 5). This stability during the technology's own instability may have helped set the foundations of a nationwide PAM research infrastructure which brought PAM applications to a higher level. That Portugal's institutional instabilities occurred during MAM's immature phase, in contrast, may have helped contribute to the episodic creation and decay of MAM know-how and likely increased the challenges in the financing of new projects in the area. CENTIMFE, the technology center in charge of technology diffusion across the molds industry, played an important role in the implementation of PAM, but a much more modest role in MAM research, perhaps because MAM was introduced at an earlier maturation stage. Although institutional changes and lack of capital availability have grown worse after the recent financial crisis, they originated well before.

In addition, and linked to MAM's ongoing technology immaturity, there is a substantial difference between PAM and MAM in how knowhow has spread across the country. PAM know-how has expanded geographically from its origins in Lisbon to the rest of the country. In contrast, for MAM research activities moved geographically from Lisbon, the capital city and main source of engineers, to Leiria, closer to the lead users of the technology in the country but with a much less developed research infrastructure, before MAM technology had become more mature. This move may have helped the process of technology diffusion, but probably also hindered the development of national capabilities due to a much lower exposure to graduate students, researchers and companies outside the molds sector. Furthermore, because most researchers who worked with MAM in the early 2000s have stayed in the Lisbon region (Interviews 7,8$),{ }^{8}$ preexisting knowhow has likely largely not supported subsequent adoption.

Proposition 4: Technology adoption may be more resilient to institutional instability as technological uncertainty decreases.

Corollary to Proposition 4: Technology adoption may become more resilient to institutional instability as the technology matures.

Previous theory have suggested that increased technical complexity can slow down technological diffusion (Rogers, 2003; Tornatzky and Klein, 1982). Here we focus instead on technological uncertainty. While complexity can contribute to the overall technological uncertainty, technological uncertainty depends on additional factors, and even in complex technologies tends to decrease as the technology matures (Bohn,

\footnotetext{
7 The same report shows a decrease of success rates for all member states. Part of this decrease can be explained by a decrease in the total amount of funding available, and by a sudden increase of newcomers, which had a success rate of 38\% (European Commission, 2015)
}

\footnotetext{
${ }^{8}$ This claim is supported by the low mobility of Portuguese entrepreneurs and their lack of willingness to move away from their home region (Figueiredo et al., 2002)
} 


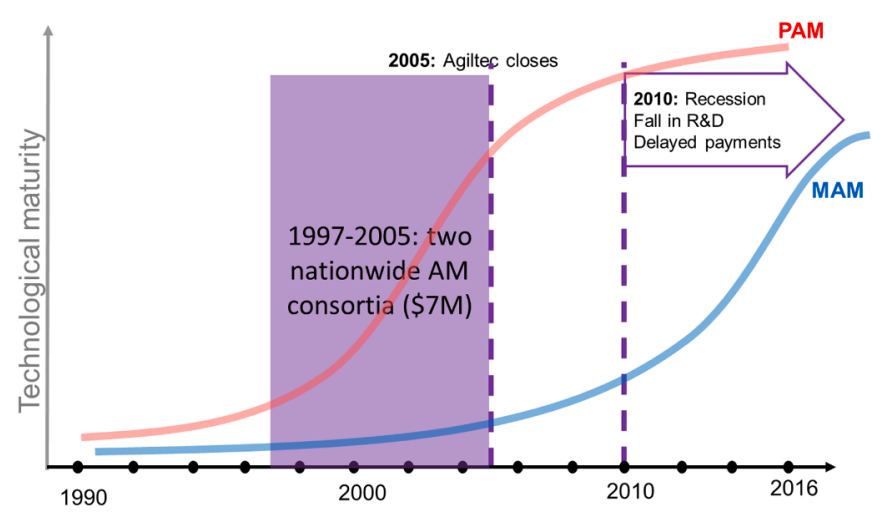

Fig. 5. Both PAM and MAM encountered institutional instability. However, MAM was less mature than PAM when that instability occurred.

2005; Bonnín Roca et al., 2017). Studies have also argued for the importance of institutional support and public funding in some cases throughout a technology's maturation stages (Cohen and Noll, 2002; Lerner, 1996; Martin and Scott, 2000), with emphasis on the gap between early experimentation and commercialization (Butler, 2008; NRC, 2004; Rogers, 2003; Weyant, 2011). With Proposition 4, we bring together existing theory on technology uncertainty (and very technology-specific characteristics creating that uncertainty) and resilience to institutional instability. Thus, our contribution lies at the intersection of studies on the need for stability in public support with theories on the maturation of a technology. Our findings go beyond existing theory by clarifying in what technology and industrial contexts support may be particularly important and how the importance of the stability of that support may change at different stages of the technology's maturation.

\section{Discussion and policy implications}

Both PAM and MAM in Portugal suffered from severe institutional instability, in the form of the destruction of key research institutions and a sudden decrease of private and public capital availability for $R \& D$ activities. Under this instability, we find PAM to have achieved greater adoption across Portugal than MAM. Building on these findings, we generate theory about what makes technologies more 'forgiving', this is, more resilient to institutional instability. We develop a generalizable framework to help policymakers understand how much institutional stability a certain technology may need to be successfully adopted in a specific industry.

\subsection{A framework of technology forgiveness}

Firms willing to adopt an emerging technology need to overcome substantial technical and market uncertainty (Nelson and Winter, 1982; Tassey, 1997). Existing literature on technology diffusion shows how diffusion rates depend largely on the perceived costs and benefits of working with the technology, the opportunities for experimentation and the ability to communicate research results to external actors (Hall, 2004; Rogers, 2003; Rosenberg, 1972). Long-term support might be needed to counteract firms' risk aversion and accelerate diffusion, but fluctuations in funding and policy goals may undermine the credibility of such public efforts (Aldrich and Fiol, 1994; Mowery et al., 2010). Less work looks at how institutional instability interacts with technological uncertainty to affect the technology diffusion process.

The commercialization of an emerging technology is subject to a combination of technology-push and market-pull forces (Linton and Walsh, 2003). Drawing from the literature and from our findings, we propose a framework that explains why some technologies are more 'forgiving' than others, specifically, why some technologies are more resilient to unexpected institutional changes. Our discussion builds most directly upon Bohn's (2005) concept of the transition 'from art to science' and Bonnin Roca et al's (2017b) analysis of how technical and contextual factors affect the uncertainty surrounding a particular technology and its maturation rate. Based on the four propositions presented in Section 5, we produce a two-dimensional framework where the forgiveness of a technology depends on both its technology-level, and industry-level, risks (Fig. 6).

Technology-level risks are those intrinsic to a technology, independently of in which industry is adopted. Some technologies might be more capital intensive than others (Preposition 1), and thus less forgiving. For instance, investing in nuclear energy inevitably requires more capital than investing in $\mathrm{AM}$, due to the size and complexity of the equipment required. In our case, MAM is technically more complex than PAM, and requires larger capital investments. In addition, some technologies might enjoy potential markets which are by nature larger or more diverse than others (Proposition 3). Larger market sizes may incentivize firms to increase both product (Acemoglu and Linn, 2004) and process (Desmet and Parente, 2010) innovation, and technologies with a wider range of applications tend to have faster diffusion rates (Gross, 2017). For example, LED lighting has many more potential applications than drugs which target a rare disease. PAM in Portugal is used in more sectors than MAM. Technologies with multiple applications are more forgiving, because if they fail to conquer one of the markets, they might still strive in another market. Finally, technologies with higher sources of technological uncertainty (Proposition 4) are less forgiving. In Section 5.3, we unpack why technological uncertainty in MAM is larger than in PAM. Per past work by Bohn (2005) and Bonnin Roca et al (2017b) these technologies are also often less mature. As technology evolves, the required capital investment and potential market applications also change (Perez and Soete, 1988; Taylor and Taylor, 2012). Hence, the technology-level dimension of forgiveness is dynamic.

Industry-level risks involve several factors related to the context in which the technology is being introduced, independently of the technology. In our case of Portugal, we focus on risks from three different components.

The first component is the predominant risk culture in the industry. As described in Section 4.1, the Portuguese molds industry is mostly composed of micro- and small-sized enterprises, often family firms. Small family firms tend to be more risk averse and more sensitive to uncertainty (Bianco et al., 2013; González et al., 2013) than non-family firms. The higher the risk-aversion, the less forgiving the sector is, as capital investments are perceived as higher (Proposition 1). Other characteristics which may affect risk-taking attitudes and investment decisions are firm age (Anderson and Eshima, 2013), cultural background (Li et al., 2013), and managerial structure (Hoskisson et al., 2017). Furthermore, companies might be more risk-averse in those areas where a failure in their products may cause a large social and reputational loss, like in aviation or pharmaceuticals.

The second component is the existence of sectorial barriers to entry, which increase risks. These barriers might be the existence of stringent regulation and certification procedures which may make the adoption of an emerging technology a slow, costly process (Bonnín Roca et al., 2017; Stewart, 1981); the presence of an incumbent technology which is cost-competitive in the present (Fuchs and Kirchain, 2010; Henderson, 1995; Rosenberg, 1972), or the need for a large capital investment (Proposition 1), especially in infrastructure industries such as energy or telecommunications (Henisz and Zelner, 2001; Narayanamurti et al, 2011). The lower the barriers to entry, the more opportunities for experimentation which help gather knowledge and dissipate uncertainty about the technology. In the case of Portugal, MAM is replacing reliable machining technologies, while PAM replaced expensive handcrafted prototyping technologies. In addition, since the early 2010s there is low-cost desktop PAM equipment and more opportunities for training. 


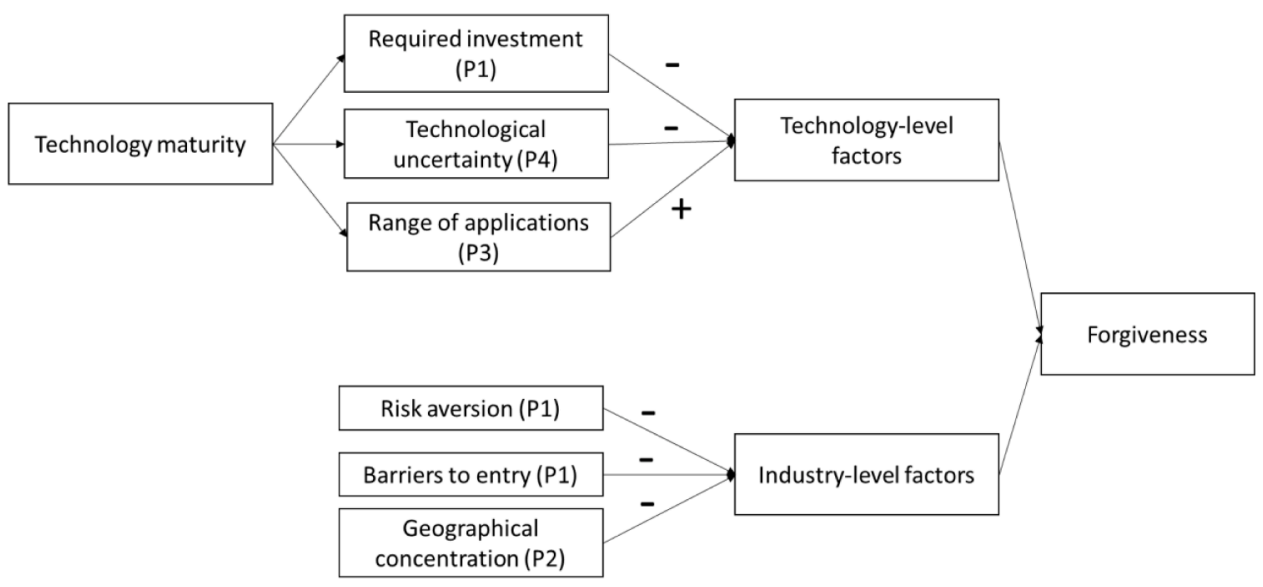

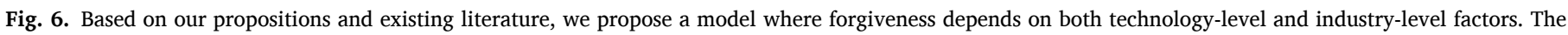
sign indicates whether we expect a proportional $(+)$, or inversely proportional (-), relationship between the variables.

The third component is the regional concentration ${ }^{9}$ of actors devoted to the development of the technology (Proposition 2). As actors become distributed across regions, they become less susceptible to "commonmode failure:" the causes a sudden weakness or failure in one of those actors, or the institutional structure which supports them, is less likely to also affect the others. In the case of Portugal, MAM research in the early stages was concentrated in Lisbon, which is also the region which suffered the highest drop in funding, and which saw the closure of ITEC, Agiltec and INETI. Our findings are consistent with Isaksen's (Isaksen, 2018) study of a once-blooming boat-building cluster in Norway, which disappeared due to the lack of support from its regional innovation system. These localized 'institutional disasters' can be metaphorically compared to natural disasters, such as the 2011 Tohoku earthquake, which disrupted the world's supply chain of automotive semiconductors (Matsuo, 2015; Sawik, 2019). The same way that geographical dispersion helps decrease the risks of supply chain disruption associated with natural disasters, it also helps reduce the negative consequences of a potential overreliance on common sources of institutional support for R\&D.

We situate a technology and its industrial context in a twodimensional plane based on its technology-level and industry-level risks (Fig. 7). On the horizontal axis is the degree of technology-level risks: this stems from factors such as whether the technology requires new testing methods or the relevance of learning-by-using (see Table 2). On the vertical axis is the degree of industry-level risks that the technology faces, but which are not inherent to the technology: these include risks associated with change in policy, and market conditions. We contend that, as the degree of contextual or inherent uncertainty associated with the technology falls, it becomes more forgiving of instability in the institutions that seek to foster its growth. We also suggest that, technologies for which both inherent and contextual uncertainties are great are less forgiving than those for which only one of those sources of uncertainty is large. An example of such cases would be MAM in aviation - where the technology is inherently uncertain, and is also subject to contextual uncertainty (e.g., onerous regulatory requirements, possibility of large human losses). Such technologies are the least forgiving to fluctuations in institutional support.

In the case of PAM in the molds industry, both technology-level and industry-level risks are low, and thus forgiveness is high. The case of MAM in the molds industry has a similar technology uncertainty as

\footnotetext{
${ }^{9}$ Here, we are using the term concentration in the Marshallian sense of knowledge and pecuniary externalities, and not of geographic concentration influenced by minimum efficient plant size (which is a technology-influenced variable) as discussed by Krugman and Chandler.
}

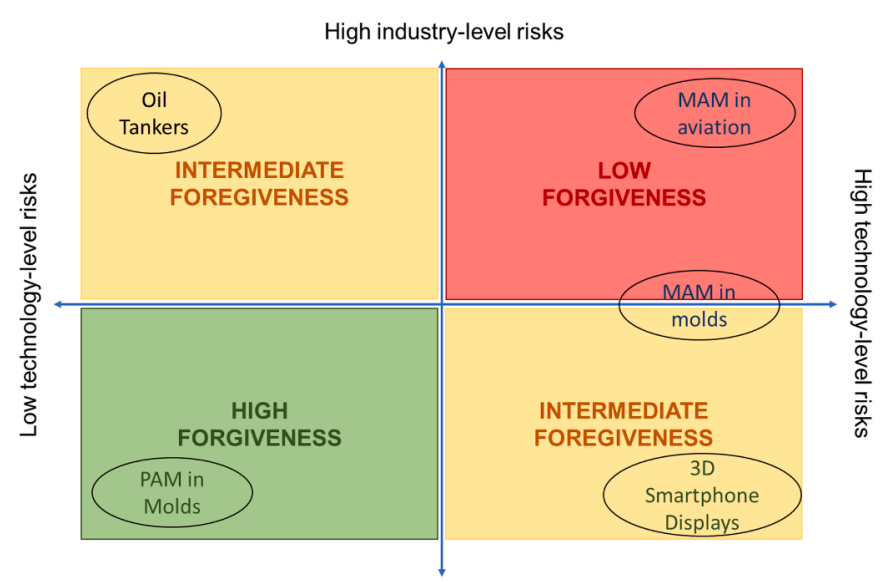

Low industry-level risks

Fig. 7. In our model, forgiveness depends on technology-level and industrylevel risks. In the case of the Portuguese molds industry, MAM would be less forgiving than PAM.

MAM in aviation (although in the case of aviation it is slightly higher because applications are more demanding), but industry-level risks are much lower given a less stringent regulatory framework, a lower capital intensity and shorter development times. At the same time, and despite being in the same industry, industry-level risks of MAM are higher than PAM in the molds industry, given that applications have completely different barriers to entry, market size and national capabilities. In particular, risk aversion for PAM applications is low, given that the prototypes made with PAM can break without large negative consequences. However, risk aversion for MAM is high, as it is used to make components for the final molds delivered to the customer, which need to be guaranteed to work for several years. Overall, that makes MAM in the molds industry is more forgiving than MAM in aviation, but less forgiving than PAM in the molds industry.

Two cases may have similar levels of forgiveness, but due to different underlying reasons. For instance, the science and engineering behind manufacturing oil tankers is well understood, and therefore technological uncertainty is low. However, the future market for oil tankers is deeply uncertain and manufacturing oil tankers requires important investments in infrastructure, and the preexistence of a strong steelmaking industry and a global demand for oil. In addition, a failure during service may cause extensive environmental losses. Conversely, if 3D displays for smartphones could be developed, they would see a strong market given that the smartphone market is mature and the consequences of a single 
failure in a device are low. However, the technical challenges presented by developing such a display are formidable.

The position of a certain technology-context in Fig. 7 is not fixed, but moves according to the maturation stage and maturation rate of the technology, and other events such as the development of standards or new regulation. In particular, we expect the forgiveness of a technology to increase with time along the horizontal axis. Some industry-level risks such as the consequences of part failure, or the need for large investment in infrastructure, affect forgiveness independently of the maturation state. Therefore, along the vertical axis, forgiveness could remain stagnant or, in some cases, even increase (e.g. new legislation more stringent than current).

Our study presents two major limitations which require further research to be addressed. First, due to the qualitative nature of our study, we are inherently unable to estimate the mathematical relationships between each of the sources of risk, as stated in our propositions, and their effect on the amount of forgiveness. Thus, we cannot evaluate the nature of the compounding effect (e.g. additive, multiplicative) resulting from the interaction of several sources of risk. This limitation can only be overcome through large-scale empirical theory-testing. Second, our study focuses on two extreme cases, PAM and MAM, where PAM presents both lower technology-level and lower industrylevel risks than MAM. To properly study the potential substitution effects between technology-level and industry-level risks on the total amount of forgiveness, future work needs to analyze a situation where one technology has higher risks than the other in one dimension, but lower in the other dimension.

\subsection{Policy implications}

The case of Portugal provides important insights for the successful adoption of other technologies in other countries. Technology followers often lack the same levels of capital and human resources that technology leaders enjoy (Krugman, 1979; Perez and Soete, 1988). The analysis of a technology using our framework may help policymakers situate the level and duration of support that a technology may need, and prevent waste of scarce public resources. As shown in Fig. 7, some technologies might be more challenging from a technical perspective. In these cases, industrial policies might focus on the need for capital availability and the development of indigenous know-how. Examples of such policies include the creation of dedicated venture capital pools (Breznitz, 2007); dedicated science parks (Armanios et al., 2017); R\&D subsidies for high-risk technologies (Feldman and Kelley, 2006); offshore R\&D outposts (Lee, 2005); or the creation of technology-focused intermediaries (Howells, 2006).

Conversely, other technologies may be less challenging from a technical perspective, but are developed in punishing industrial contexts. In this case, policies might target the creation of an early, stable market. For instance, governments may want to create public-private partnerships with specific companies to ensure a minimum demand for their products, as happened for instance with SpaceX (C. Anderson, 2013). The promotion of FDI may help create and further develop a network of suppliers (Reis et al, 2016). Public subsidies, like in the case of solar photovoltaic, may help reduce the difference in cost between the incumbent and the emerging technologies (Morton, 2006). Cases which are both technologically and contextually challenging such as MAM in aeronautics are especially risky, and countries may want to explore the possibility of promoting those technologies in less challenging industrial contexts associated with a national mission or need.

In the last decades, there has been a surge in the interest among policymakers in the creation of technology clusters to develop competitive regional industries, stimulated through specific funding mechanisms (Porter, 1996; Vanhove, 2018). These policies are motivated by extensive empirical evidence that suggests that geographical proximity and cluster effects might help achieve economies of scale, create opportunities for collaboration and the pooling of resources, and facilitate knowledge spillovers (Asheim and Coenen, 2005; Clark, 1984; Cooke, 2001; Gertler, 1995; Munari et al., 2012, 2012). Supporting policies need to accompany technology development during their expected time-to-market, which in some cases may be decades (Bonnin Roca and O'Sullivan, 2020; Said et al., 2012). Our findings suggest, however, that these same cluster forces might also be the source of potential technology lock-out, as the key actors in the innovation system (e.g. technology centers) in charge of facilitating technology diffusion might become a self-reinforcing mechanism to prevent innovation. Investment decisions at these organizations are driven by the interests of both the organization itself, which needs to be financially sustainable, and its industry members, who may focus on short-term incremental projects rather than on long-term strategic goals. In our case of the Portuguese molds industry, these attitudes appear to be further encouraged by institutional instability.

Policies to foster the adoption of less forgiving technologies need the establishment of a long-term public "credible commitment" (North and Weingast, 1989) to attract private investment, in the form of specific regulation, tax policies, or a new long-term direction of the science and technology policy (Bergek et al., 2008b). To ensure the continuity of these policies, it is likely that governments would require multi-partisan support (Branscomb, 1997). An option to estimate the amount of support needed in the long-term is the creation of strategic industry roadmaps highlighting the interdependencies between technological development and public policy, in the short-, mid-, and long-terms (Ho and O'Sullivan, 2017; Walsh, 2004). Otherwise, changes in the political environment may introduce additional instability, such as the introduction of retroactive measures in existing installations in the Spanish energy market, may lead to a market bust (del Río and Mir-Artigues, 2012). After support for a certain technology has been disrupted, it may be very difficult to recover. Our findings suggest that the later acquisition of a MAM machine by CDRSP had little impact on MAM's research or industry's perspective on the potential of the technology. Thus, instability may help create a negative feedback loop, as shown in Fig. 8. Without institutional support, the leading Portuguese SMEs started experimenting with MAM on their own. Because MAM entailed a large technological uncertainty, and MAM products have stringent specifications, most of these early experiments in the private sector were disappointing, causing firms to lose interest in MAM.

The institutional stability we propose should not be confused with institutional rigidity. In fact, existing literature shows that institutions in charge of technology upgrading need to be flexible to adapt to rapid technological changes (Amsden \& Chu, 2003; Breznitz, 2007). Indeed, regulators may need to periodically revise their policies in order to avoid situations of 'regulatory lock-in', where regulation written while the

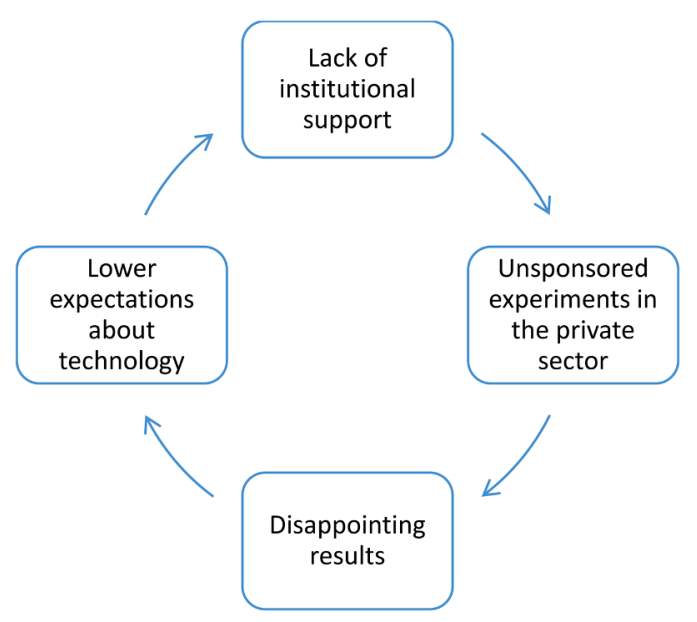

Fig. 8. The Portuguese industry may have entered a negative feedback loop in the introduction of MAM. 
technology is immature may constrain the long-term potential of a technology (Bonnín Roca et al., 2016; Keith et al., 2010).

\section{Conclusion}

Our work presents a comparative case study of the diffusion of two emerging process-based technologies, polymer and metallic additive manufacturing (PAM and MAM), in Portugal, a resource-constrained technology follower, given institutional instability. Although MAM may be instrumental to long-term global competitiveness for the Portuguese molds industry, MAM's adoption has been much lower than PAM's. We develop new theory for how the different technological characteristics and industrial contexts of PAM and MAM interact with institutional instability during early technology adoption such that one technology (PAM) achieves widespread adoption, while the other (MAM), does not. Specifically, we generate theory about how technology-level and industry-level risks, determined by the maturation state and maturation rate of a technology, influence the 'forgiveness' of that technology, defined as the susceptibility of the adoption of a certain technology to institutional instability. Based on the lessons from our cases, we propose a new framework on how to think about generalizing our findings to other technologies and industrial contexts. For successful adoption, countries willing to invest in less-forgiving technologies may need to simultaneously invest in long-term policies related to funds and the development of necessary national know-how.

\section{CRediT authorship contribution statement}

Jaime Bonnín Roca: Conceptualization, Methodology, Investigation, Writing - original draft, Visualization. Parth Vaishnav: Writing review \& editing, Supervision, Conceptualization, Resources, Visualization. Granger M. Morgan: Conceptualization, Writing - review \& editing, Supervision, Project administration, Funding acquisition, Resources. Erica Fuchs: Conceptualization, Writing - review \& editing, Supervision, Resources. Joana Mendonça: Conceptualization, Supervision, Project administration, Funding acquisition, Resources.

\section{Acknowledgments}

This work was supported by Carnegie Mellon University and the CMU-Portugal program, as well as funding from the Portuguese Foundation for Science and Technology (FCT), under project reference CMUP-ERI/TPE/0011/2013. We thank all the academics, regulators and industry members who spent countless hours answering our questions. All the errors remain our own.

\section{Appendix: Interviews conducted}

Table 3 Interviews Conducted

\begin{tabular}{|c|c|c|c|}
\hline Sector/Organization & Position & Date & Cited As \\
\hline \multicolumn{4}{|l|}{ Firms } \\
\hline Aeronautics-1 & R\&D Manager & 4-Feb-16 & 26 \\
\hline Aeronautics-1 & Metallic Producs & 4-Feb-16 & \\
\hline Aeronautics-2 & Maintenance & 18-Mar-16 & \\
\hline Aeronautics-3 & Process Engineer & 7-Apr-16 & 27 \\
\hline Automotive-1 & Process Engineer & 7-Apr-16 & 28 \\
\hline Biomedical-1 & CEO & 17-Feb-16 & 24 \\
\hline 3D-Printing Education & CEO & 17-Feb-16 & \\
\hline Engineering and Design-1 & General Manager & 5-May-16 & 15 \\
\hline Engineering and Design-2 & General Manager & 3-Mar-16 & 16 \\
\hline Engineering and Design-3 & General Manager & 3-Mar-16 & 10 \\
\hline Engineering and Design-4 & $\mathrm{CEO}$ & 22-Feb-16 & \\
\hline Engineering and Design-5 & Manager & 9-Sep-16 & 30 \\
\hline Machinery-1 & Сто & 12-Jul-16 & \\
\hline Machinery-1 & CEO & 12-Jul-16 & \\
\hline Machinery-2 & Co-Owner & 19-Apr-16 & \\
\hline Machinery-3 & Managing Director & 11-Mar-16 & 22 \\
\hline Molds and Tooling -1 & Technical Manager & 10-Mar-16 & 1 \\
\hline Molds and Tooling - 1 & CFO & 23-Feb-16 & 2 \\
\hline Molds and Tooling -2 & Director, Prototyping & 3-Mar-16 & 3 \\
\hline Molds and Tooling -3 & Technical Manager & $3 / 18 / 2016$ and $4 / 6 / 2016$ & 4 \\
\hline Molds and Tooling -4 & MAM Expert & 25-Jul-16 & 5 \\
\hline Molds and Tooling -5 & R\&D Engineer & 21-Apr-16 & 14 \\
\hline \multicolumn{4}{|l|}{ Industry Organizations } \\
\hline Industry Association - 1 & Technical Director & 28-Sep-16 & \\
\hline Industry Association - 2 & R\&D Head & 19-Apr-16 & \\
\hline Industry Association - 3 & R\&D Coordinator & 2-Mar-16 & 30 \\
\hline Technology Center -1 & President & December, 2015 & \\
\hline Technology Center -1 & R\&D Head & Several & 20 \\
\hline Technology Center -1 & Prototyping & 30-Jan-17 & 6 \\
\hline Technology Center -2 & R\&D Head & 1-Mar-16 & 21 \\
\hline Technology Center -2 & Financial Director & 1-Mar-16 & \\
\hline \multicolumn{4}{|l|}{ Research institutions } \\
\hline Research institution-1 & R\&D Coordinator & 1-Mar-16 & 19 \\
\hline Research institution-1 & Head of Prototyping & 19-Jul-16 & \\
\hline Research institution-2 & Member of Board & 28-Sep-16 & 23 \\
\hline Research institution-3 & Adjunct Director & 30-Jun-16 & 18 \\
\hline Research institution-4 & PAM Research & 4-Mar-16 & 12 \\
\hline Research institution-5 & Member of Board & $3 / 10 / 2016$ and $5 / 5 / 2016$ & 9 \\
\hline Research institution-6 & Advanced Manufacturing & 28-Sep-16 & 17 \\
\hline
\end{tabular}


(continued)

\begin{tabular}{llll}
\hline Sector/Organization & Position & Date & Cited As \\
\hline Research institution-6 & Product Development & $2-$ Mar-16 & 13 \\
Research institution-7 & PAM Research & $23-$ Feb-16 & 11 \\
Research institution-7 & MAM Pioneer & $31-$ Mar-16 & 7 \\
Research institution-7 & MAM Pioneer & $1-$ Apr-16 & \\
Other & & & \\
Training Center-1 & Head of Training & 6-Apr-16-16-16 \\
Training Center-2 & General Manager & 19-May-16 \\
Makerspace-1 & Director & 19-Jul-16 \\
Government-1 & Innovation Policy & & 25 \\
\hline
\end{tabular}

\section{References}

3ders.org 2014 3ders.org, 2014. China developing world's largest 3D printer, prints $6 \mathrm{~m}$ metal parts in one piece [WWW Document]. 3ders.org. URL http://www.3ders.org/articles/20140207-china-developing-worldlargest-3d-printer-prints-6m-metal-parts-in-one-piece.html (accessed 10.24.15).

3ders.org 2016 3ders.org, 2016. Adira unveils world's first Tiled Laser Melting metal 3D printer with biggest ever build volume [WWW Document]. URL http://www.3ders.org/articles/20161103-adira-unveils-worlds-firsttiled-laser-melting-metal-3d-printer-with-biggest-ever-build-volume. html (accessed 3.7.17).

Abdollahi, S., Boktor, J., Hibino, N., 2019. Bioprinting of freestanding vascular grafts and the regulatory considerations for additively manufactured vascular prostheses. Transl. Res. 211, 123-138. https://doi.org/10.1016/j.trsl.2019.05.005.

Acemoglu, D., Linn, J., 2004. Market size in innovation: theory and evidence from the pharmaceutical industry. Q. J. Econ. 119, 1049-1090, 10.1162/ 0033553041502144.

AdI, 2003. FRF - Fabrico Rápido de Ferramentas [WWW Document]. URL http:// projectos.adi.pt/actions/project?id=C15/2001/ $0001 \&$ search $=$ global\&actionbean $=$ actions/project (accessed 1.24.17)

Alabi, M.O., De Beer, D., Wichers, H., 2019. Applications of additive manufacturing at selected South African universities: promoting additive manufacturing education. Rapid Prototyp. J. 25, 752-764. https://doi.org/10.1108/RPJ-08-2018-0216.

Aldrich, H.E., Fiol, C.M., 1994. Fools rush in? The institutional context of industry creation. Acad. Manage. Rev. 19, 645-670. https://doi.org/10.2307/258740.

Amsden, A.H., Chu, W., 2003. Beyond Late Development: Taiwan's Upgrading Policies. The MIT Press, (MIT Press Books).

Anderson, B.S., Eshima, Y., 2013. The influence of firm age and intangible resources on the relationship between entrepreneurial orientation and firm growth among Japanese SMEs. J. Bus. Ventur. 28, 413-429. https://doi.org/10.1016/j. jbusvent.2011.10.001.

Anderson, C., 2013a. Rethinking public-private space travel. Space Policy 29, 266-271. https://doi.org/10.1016/j.spacepol.2013.08.002.

Anderson, E., 2013b. Additive manufacturing in China: threats, opportunities, and Developments (Part II). SITC Bull. Anal.

Anderson, P., Tushman, M.L., 2001. Organizational environments and industry exit: the effects of uncertainty, Munificence and Complexity. Ind. Corp. Change 10, 675-711. https://doi.org/10.1093/icc/10.3.675.

Andersson, M., Ejermo, O., 2005. How does accessibility to knowledge sources affect the innovativeness of corporations?- - evidence from Sweden. Ann. Reg. Sci. 39, 741-765. https://doi.org/10.1007/s00168-005-0025-7.

Armanios, D.E., Eesley, C.E., Li, J., Eisenhardt, K.M., 2017. How entrepreneurs leverage institutional intermediaries in emerging economies to acquire public resources: How Entrepreneurs Leverage Institutional Intermediaries in Emerging Economies. Strateg. Manag. J. 38, 1373-1390, 10.1002/smj.2575.

Arthur, W.B., 1989. Competing technologies, increasing returns, and lock-in by historical events. Econ. J. 99, 116, 10.2307/2234208.

Asheim, B.T., Coenen, L., 2005. Knowledge bases and regional innovation systems: comparing nordic clusters. Res. Policy 34, 1173-1190, 10.1016/j. respol.2005.03.013.

Asheim, B.T., Isaksen, A., 1997. Location, agglomeration and innovation: towards regional innovation systems in Norway? Eur. Plan. Stud. 5, 299-330, 10.1080/ 09654319708720402

Augusto Mateus \& Associados, 2013. 25 anos de Fundos Estruturais: Olhares sobre a evolução da sociedade. da economia e das instituições.

Balassa, B., 1965. Trade Liberalisation and "Revealed" comparative advantage. Manch. Sch. 33, 99-123, 10.1111/j.1467-9957.1965.tb00050.x.

Baumers, M., Dickens, P., Tuck, C., Hague, R., 2016. The cost of additive manufacturing machine productivity, economies of scale and technology-push. Technol. Forecast. Soc. Change 102, 193-201. https://doi.org/10.1016/j.techfore.2015.02.015.

Baumers, M., Holweg, M., 2019. On the economics of additive manufacturing: Experimental findings. J. Oper. Manag. 65, 794-809. https://doi.org/10.1002/ joom.1053.

BCC Research, 2016. Global Markets for 3D-Printing (No. IAS102B).

BeeVeryCreative, 2016. BEEVERYCREATIVE - Imprint change with 3D printing [WWW Document]. URL https://beeverycreative.com/order-here/ (accessed 9.14.16).
Bergek, A., Jacobsson, S., Carlsson, B., Lindmark, S., Rickne, A., 2008a. Analyzing the functional dynamics of technological innovation systems: a scheme of analysis. Res. Policy 37, 407-429. https://doi.org/10.1016/j.respol.2007.12.003.

Bergek, A., Jacobsson, S., Sandén, B.A., 2008b. 'Legitimation' and 'development of positive externalities': two key processes in the formation phase of technological innovation systems. Technol. Anal. Strateg. Manag. 20, 575-592. https://doi.org/ 10.1080/09537320802292768.

Bevan, A., Estrin, S., Meyer, K., 2004. Foreign investment location and institutional development in transition economies. Int. Bus. Rev. 13, 43-64. https://doi.org 10.1016/j.ibusrev.2003.05.005.

Bianco, M., Bontempi, M.E., Golinelli, R., Parigi, G., 2013. Family firms’ investments, uncertainty and opacity. Small Bus. Econ. 40, 1035-1058.

Bogers, M., Hadar, R., Bilberg, A., 2016. Additive manufacturing for consumer-centric business models: Implications for supply chains in consumer goods manufacturing. Technol. Forecast. Soc. Change 102, 225-239. https://doi.org/10.1016/j. techfore.2015.07.024.

Bohn, R.E., 1995. Noise and learning in semiconductor manufacturing. Manag. Sci. 41, 31.

Bohn, R.E., 2005. From art to science in manufacturing: the evolution of technological knowledge. Found. Trends® Technol. Inf. Oper. Manag. 1, 1-82. https://doi.org/ 10.1561/0200000002.

Bonnin Roca, J., O'Sullivan, E., 2020. Seeking coherence between barriers to manufacturing technology adoption and innovation policy. Int. J. Prod. Econ. 230, 107818, 10.1016/j.ijpe.2020.107818.

Bonnín Roca, J., Vaishnav, P., Fuchs, E., Morgan, M.G., 2016. Policy needed for additive manufacturing. Nat. Mater.

Bonnín Roca, J., Vaishnav, P., Laureijs, R.E., Mendonça, J., Fuchs, E.R.H., 2019. Technology cost drivers for a potential transition to decentralized manufacturing. Addit. Manuf. 28, 136-151. https://doi.org/10.1016/j.addma.2019.04.010.

Bonnín Roca, J., Vaishnav, P., Morgan, M.G., Mendonça, J., Fuchs, E., 2017. When risks cannot be seen: regulating uncertainty in emerging technologies. Res. Policy 46 1215-1233, 10.1016/j.respol.2017.05.010.

Boschma, R., 2005. Proximity and innovation: a critical assessment. Reg. Stud. 39, 61-74. https://doi.org/10.1080/0034340052000320887.

Branscomb, L.M., 1997. From technology politics to technology policy. Issues Sci. Technol. Wash. 13, 41-48.

Bresnahan, T., Greenstein, S., Brownstone, D., Flamm, K., 1996. Technical progress and Co-Invention in computing and in the uses of computers. Brook. Pap. Econ. Act. Microecon. 1-83. https://doi.org/10.2307/2534746, 1996.

Breznitz, D., 2007. Innovation and the State: Political Choice and Strategies for Growth in Israel. Yale University Press, Taiwan, and Ireland.

Brown, J.S., Duguid, P., 2001. Knowledge and organization: a social-practice perspective. Organ. Sci. 12, 198-213, 10.1287/orsc.12.2.198.10116.

Buckley, P.J., Ruane, F., 2006. Foreign direct investment in Ireland: policy implications for emerging economies. World Econ 29, 1611-1628, 10.1111/j.14679701.2006.00860.x.

Butler, D., 2008. Translational research: crossing the valley of death. Nature 453, 840-842. https://doi.org/10.1038/453840a.

Cabrini, M., Lorenzi, S., Pastore, T., Pellegrini, S., Ambrosio, E.P., Calignano, F., Manfredi, D., Pavese, M., Fino, P., 2016. Effect of heat treatment on corrosion resistance of DMLS AlSi10Mg alloy. Electrochimica Acta 206, 346-355, 10.1016/j. electacta.2016.04.157.

Campbell, R.I., de Beer, D.J., Pei, E., 2011. Additive manufacturing in South Africa: building on the foundations. Rapid Prototyp. J. 17, 156-162. https://doi.org/ 10.1108/13552541111113907.

Carlsson, B., Stankiewicz, R., 1991. On the nature, function and composition of technological systems. J. Evol. Econ. 1, 93-118. https://doi.org/10.1007/ BF01224915.

CATIM, 2017. MACPME [WWW Document]. Proj. MACPME. URL http://www.catim.pt/ en/macpme (accessed 3.7.17).

CDRSP, 2014. Research Portfolio.

CEFAMOL, 2016. A Industria Portuguesa de Moldes.

CEFAMOL, 2017. A Indústria de Moldes em Portugal: Exportações atingem número recorde em 2016 [WWW Document]. URL http://www.cefamol.pt/cefamol/pt/Cef amol_ACefamol/Noticias/PloneArticle.2017-02-22.6188595523 (accessed 10.28.17).

Cegarra-Sánchez, J., Cegarra-Navarro, J.-G., Chinnaswamy, A.K., Wensley, A., 2020. Exploitation and exploration of knowledge: An ambidextrous context for the successful adoption of telemedicine technologies. Technol. Forecast. Soc. Change 157, 120089, 10.1016/j.techfore.2020.120089. 
Chari, V.V., Hopenhayn, H., 1991. Vintage human capital, growth, and the diffusion of new technology. J. Polit. Econ. 99, 1142-1165.

Clark, G., 1984. Innovation diffusion : contemporary geographical approaches. Geo Books.

Cohen, L.R., Noll, R.G., 2002. The technology pork barrel. Brookings Institution Press. COMPETE, 2014. Programa Operacional Competitividade e Internacionalizacao.

Contzen, J.-P., Fereres, E., Papon, P., Popp, M., 2006. Redesigning the governance of the state laboratories' system. Lisbon.

Cooke, P., 1992. Regional innovation systems: competitive regulation in the new Europe. Geoforum 23, 365-382, 10.1016/0016-7185(92)90048-9.

Cooke, P., 2001. Regional innovation systems, clusters, and the knowledge Economy. Ind. Corp. Change 10, 945-974. https://doi.org/10.1093/icc/10.4.945.

Cooke, P., Gomez Uranga, M., Etxebarria, G., 1997. Regional innovation systems: Institutional and organisational dimensions. Res. Policy 26, 475-491. https://doi. org/10.1016/S0048-7333(97)00025-5.

CORDIS, 1991. Instantcam: reduction of design to product lead time through instant manufacturing of models, prototypes and tools [WWW Document. CORDIS Proj. Results Serv. URL http://cordis.europa.eu/project/rcn/921_en.html (accessed 8.14.16).

CORDIS, 2002. Rapid prototyping and tooling industrial applications [WWW Document]. URL http://cordis.europa.eu/project/rcn/46840_en.html (accessed 2.8.17).

CORDIS, 2013. European commission : CORDIS: projects \& results service: final report summary - IMPALA (Intelligent manufacture from powder by advanced laser assimilation) [WWW Document]. URL http://cordis.europa.eu/result/rcn/54444 en.html (accessed 9.16.16).

Cunha, S.V.L.D., 1993. Educational reforms in Portugal: helping to raise the profile of VET. Eur. J. Educ. 28, 215, 10.2307/1503388.

Cusumano, M.A., Mylonadis, Y., Rosenbloom, R.S., 1992. Strategic maneuvering and mass-market dynamics: the triumph of VHS over beta. Bus. Hist. Rev. 66, 51-94. https://doi.org/10.2307/3117053.

de Jong, J.P., de Bruijn, E., 2013. Innovation lessons from 3-D printing. MIT Sloan Manag. Rev. Camb. 54, 43-52.

de Solla Price, D.J., 1984. Of sealing wax and string. Nat. Hist. 93, 49-56.

del Río, P., Mir-Artigues, P., 2012. Support for solar PV deployment in Spain: some policy lessons. Renew. Sustain. Energy Rev. 16, 5557-5566. https://doi.org/10.1016/j. rser.2012.05.011.

Denzin, N.K., Lincoln, Y., 2011. The SAGE Handbook of Qualitative Research, Edición: 4th Revised edition. SAGE Publications, Inc, Thousand Oaks.

Department of Energy, 1989. From invention to innovation: commercialization of new technology by independent and small business inventors.

Desmet, K., Parente, S.L., 2010. Bigger is better: market size, demand elasticity, and innovation. Int. Econ. Rev. 51, 319-333. https://doi.org/10.1111/j.14682354.2010.00581.x.

Diários da República, 2006. Resolução do Conselho de Ministros 124/2006, de 3 de Outubro [WWW Document. Diários Repúb. URL https://dre.tretas.org/dre/202224/ resolucao-do-conselho-de-ministros-124-2006-de-3-de-outubro (accessed 1.24.17).

DiMaggio, P.J., Powell, W.W., 1983. The iron cage revisited: institutional isomorphism and collective rationality in organizational fields. Am. Sociol. Rev. 48, 147-160.

Dolenc, A., 1994. An overview of rapid prototyping technologies in manufacturing.

Downer, J., 2017. The aviation paradox: why we can 'Know' jetliners but not reactors. Minerva 55, 229-248. https://doi.org/10.1007/s11024-017-9322-4.

Dresselhaus, M.S., Thomas, I.L., 2001. Alternative energy technologies [WWW Document]. Nature. https://doi.org/10.1038/35104599.

Eisenhardt, K.M., 1989. Building theories from case study research. Acad. Manage. Rev. 14, 532-550. https://doi.org/10.5465/AMR.1989.4308385.

EOS, 2017. About EOS | History [WWW Document]. URL https://www.eos.info/about eos/history (accessed 5.31.17).

Esperto, L., Osório, A., 2008. Rapid tooling Sinterização Directa por Laser de. Metais. Rev. Assoc. Port. Análise Exp. Tensões ISSN 1646, 7078.

EUR-Lex - 32013R1303 [WWW Document], 2013. URL http://eur-lex.europa.eu/legalcontent/EN/TXT/?uri=celex\%3A32013R1303 (accessed 1.25.17).

European Commission, 2007. Research for SMEs and Research for SME Associations at Glance: the FP7 funding model. Office for Official Publications of the European Communities, Luxembourg.

European Commission, 2014. Additive Manufacturing in FP7 and Horizon 2020. Report from the EC Workshop on Additive Manufacturing held on 18 June 2014.

European Commission, 2015. Horizon 2020: first results. Publications Office, Luxembourg.

European Commission, 2016. Work Programme 2016-17. General Annexes. D. Types of action: specific provisions and funding rates.

European Innovation Scoreboard, 2016. European innovation scoreboard - Crecimiento European Commission [WWW Document]. Crecimiento. URL http://ec.europa.eu/ growth/industry/innovation/facts-figures/scoreboards_es (accessed 9.15.16).

Fagerberg, J., Godinho, M.M., 2005. Innovation and catching-up. Oxf. Handb. Innov. Oxf. Univ, Press N. Y, pp. 514-543.

Fagerberg, J., Srholec, M., 2008. National innovation systems, capabilities and economic development. Res. Policy 37, 1417-1435, 10.1016/j.respol.2008.06.003.

Faria, L., 1999. Integration of rapid proto typing techniques in the manufacturing chain process of the foundry industry - Final Report (No. NATO-Sf'S-PO-PROTOTYPING).

Feldman, M.P., Kelley, M.R., 2006. The ex ante assessment of knowledge spillovers: Government R\&D policy, economic incentives and private firm behavior. Res. Policy 35, 1509-1521, 10.1016/j.respol.2006.09.019.

Ferraz, J.C., Kupfer, D., 1999. Macro/Micro Interactions: Economics and Institutional Uncertainties and Structural Change in.. Oxf. Dev. Stud. 27, 279.
Figueiredo, O., Guimarães, P., Woodward, D., 2002. Home-field advantage: location decisions of Portuguese entrepreneurs. J. Urban Econ. 52, 341-361. https://doi.org/ 10.1016/S0094-1190(02)00006-2.

Fleck, J., 1994. Learning by trying: the implementation of configurational technology. Res. Policy 23, 637-652.

Fontana, R., 2008. Competing technologies and market dominance: standard "battles" in the Local Area Networking industry. Ind. Corp. Change 17, 1205-1238, 10.1093/ icc/dtn043.

Frazier, W.E., 2014. Metal additive manufacturing: a review. J. Mater. Eng. Perform. 23, 1917-1928. https://doi.org/10.1007/s11665-014-0958-z.

Freeman, C., 2002. Continental, national and sub-national innovation systems - complementarity and economic growth. Res. Policy 31, 191-211, 10.1016/S0048-7333(01)00136-6.

Freeman, R.B., van Reenen, J., 2008. Be careful what you wish for: a cautionary tale about budget doubling. Issues Sci. Technol. 25, 27.

Fuchs, E., Kirchain, R., 2010. Design for location? The impact of manufacturing offshore on technology competitiveness in the optoelectronics industry. Manag. Sci. 56, 2323-2349. https://doi.org/10.1287/mnsc.1100.1227.

Furman, J.L., Hayes, R., 2004. Catching up or standing still?: National innovative productivity among 'follower' countries, 1978-1999. Res. Policy, What do we know Innovation? Selected papers from an International Conference in honour of Keith Pavitt 33, 1329-1354, 10.1016/j.respol.2004.09.006.

Gallego, J.M., Gutiérrez, L.H., Lee, S.H., 2015. A firm-level analysis of ICT adoption in an emerging economy: evidence from the Colombian manufacturing industries. Ind. Corp. Change 24, 191-221, 10.1093/icc/dtu009.

Gartner, J., Fink, M., 2018. The magic cube: towards a theoretical framework to explain the disruptive potential of additive manufacturing. Transl. Mater. Res. 5, 024003 , 10.1088/2053-1613/aaca53.

Gatto, M., Harris, R.A., 2011. Non-destructive analysis (NDA) of external and internal structures in 3DP. Rapid Prototyp. J. 17, 128-137. https://doi.org/10.1108/ 13552541111113871.

GE, 2016. GE makes progress with investments in additive equipment companies | GE Additive [WWW Document]. URL http://www.geadditive.com/press-releases/gemakes-progress-with-investments-in-additive-equipment-companies (accessed 8.29.17).

Gebler, M., Schoot Uiterkamp, A.J.M., Visser, C., 2014. A global sustainability perspective on 3D printing technologies. Energy Policy 74, 158-167. https://doi. org/10.1016/j.enpol.2014.08.033.

Geroski, P.A., Gregg, P., 1997. Coping with Recession. Cambridge University Press, UK Company Performance in Adversity.

Gertler, M.S., 1995. Being There": proximity, organization, and culture in the development and adoption of advanced manufacturing technologies. Econ. Geogr. 71, 1-26. https://doi.org/10.2307/144433.

Ghobadian, A., Talavera, I., Bhattacharya, A., Kumar, V., Garza-Reyes, J.A., O'Regan, N., 2020. Examining legitimatisation of additive manufacturing in the interplay between innovation, lean manufacturing and sustainability. Int. J. Prod. Econ. 219, 457-468, 10.1016/j.ijpe.2018.06.001.

Gibson, I., Rosen, D.W., Stucker, B., 2010. Additive Manufacturing Technologies. Springer US, Boston, MA.

Glimstedt, H., 2001. Competitive dynamics of technological standardization: the case of third generation cellular communications. Ind. Innov. 8, 49-78. https://doi.org/ 10.1080/13662710120034400.

Gnyawali, D.R., Park, B.-J., (Robert), 2009. Co-opetition and technological innovation in small and medium-sized enterprises: a multilevel conceptual model. J. Small Bus. Manag. 47, 308-330. https://doi.org/10.1111/j.1540-627X.2009.00273.x.

Godinho, M.M., Mamede, R.P., 2016. Southern Europe in crisis: industrial policy lessons from Italy and Portugal. Econ. E Polit. Ind. https://doi.org/10.1007/s40812-0160037-6.

Goldfarb, B., 2005. Diffusion of general-purpose technologies: understanding patterns in the electrification of US Manufacturing 1880-1930. Ind. Corp. Change 14, 745-773, 10.1093/icc/dth068.

Goldstein, M., Bergsten, C.F., 1998. The Asian Financial Crisis: Causes, Cures, and Systemic Implications. Institute for International Economics, Washington, DC.

González, M., Guzmán, A., Pombo, C., Trujillo, M.-A., 2013. Family firms and debt: risk aversion versus risk of losing control. J. Bus. Res. 66, 2308-2320. https://doi.org/ 10.1016/j.jbusres.2012.03.014.

Gordon, MacLeod, 2002. New regionalism reconsidered: globalization and the remaking of political economic space. Int. J. Urban Reg. Res. 25, 804-829. https://doi.org/ 10.1111/1468-2427.00345.

Griliches, Z., 1957. Hybrid corn: an exploration in the economics of technological change. Econometrica 25, 501-522. https://doi.org/10.2307/1905380.

Gross, D.P., 2017. Scale versus scope in the diffusion of new technology: evidence from the farm tractor (Working Paper No. 24125). National Bureau of Economic Research. https://doi.org/10.3386/w24125.

Guillot, C., 2017. More universities are offering degrees in additive manufacturing ChiefExecutive.net | [WWW Document]. ChiefExecutivenet Chief Exec. Mag. URL http://chiefexecutive.net/universities-offering-degrees-additive-manufacturing/ (accessed 8.31.17).

Hall, B.H., 2004. Innovation and Diffusion (Working Paper No. 10212). Natl. Bureau Econ. Res. https://doi.org/10.3386/w10212.

Harris, I.D., 2011. Development and Implementation of Metals Additive Manufacturing. DOT Int, New Orleans.

Hebert, R.J., 2016. Viewpoint: metallurgical aspects of powder bed metal additive manufacturing. J. Mater. Sci. 51, 1165-1175. https://doi.org/10.1007/s10853-0159479-x. 
Hekkert, M.P., Suurs, R.A.A., Negro, S.O., Kuhlmann, S., Smits, R.E.H.M., 2007. Functions of innovation systems: A new approach for analysing technological change. Technol. Forecast. Soc. Change 74, 413-432, 10.1016/j. techfore.2006.03.002.

Helveston, J.P., Wang, Y., Karplus, V., Fuchs, E.R.H., 2016. Up, down, and sideways: innovation in china and the case of plug-in electric vehicles. SSRN Electron. J. https://doi.org/10.2139/ssrn.2817052.

Henderson, R., 1995. Of life cycles real and imaginary: The unexpectedly long old age of optical lithography. Res. Policy 24,631-643. https://doi.org/10.1016/S0048-7333 (94)00790-X.

Henisz, W.J., 2002. The institutional environment for infrastructure investment. Ind. Corp. Change 11, 355-389, 10.1093/icc/11.2.355.

Henisz, W.J., Zelner, B.A., 2001. The Institutional Environment for Telecommunications Investment. J. Econ. Manag. Strategy 10, 123-147. https://doi.org/10.1111/j.1430 9134.2001.00123.x.

Henriques, E., Osório, A., 2002. Prototipagem Rápida en Portugal.

Ho, J.-Y., O'Sullivan, E., 2017. Strategic standardisation of smart systems: a roadmapping process in support of innovation. Technol. Forecast. Soc. Change 115 301-312. https://doi.org/10.1016/j.techfore.2016.04.014.

Holbrook, D., Cohen, W.M., Hounshell, D.A., Klepper, S., 2000. The nature, sources, and consequences of firm differences in the early history of the semiconductor industry. Strateg. Manag. J. 21, 1017-1041.

Hooghe, L., 1995. Subnational mobilisation in the European union. West Eur. Polit. 18, 175-198. https://doi.org/10.1080/01402389508425097.

Hopkins, M.M., Crane, P.A., Nightingale, P., Baden-Fuller, C., 2013. Buying big into biotech: scale, financing, and the industrial dynamics of UK biotech, 1980-2009. Ind. Corp. Change 22, 903-952, 10.1093/icc/dtt022.

Hoskisson, R.E., Chirico, F., Zyung, J., , (Daniel), Gambeta, E., 2017. Managerial risk taking: a multitheoretical review and future research agenda. J. Manag. 43, 137-169. https://doi.org/10.1177/0149206316671583.

Howells, J., 2006. Intermediation and the role of intermediaries in innovation. Res. Policy 35, 715-728, 10.1016/j.respol.2006.03.005.

INE, 2011. Censos 2011. Instituto Nacional de Estatística.

Interreg, 2016. Programa Interreg Sudoe - Plataforma de difusión y transferencia de tecnologías de fabricación aditiva en el sector aeroespacial del SUDOE [WWW Document]. URL https://www.interreg-sudoe.eu/proyectos/los-proyectosaprobados/160-plataforma-de-difusion-y-transferencia-de-tecnologias-defabricacion-aditiva-en-el-sector-aeroespacial-del-sudoe (accessed 2.8.17).

IPL and SLM, 2012. Public Contract No. 09/IPL/2012.

Isaksen, A., 2018. From success to failure, the disappearance of clusters: a study of a Norwegian boat-building cluster. Camb. J. Reg. Econ. Soc. 11, 241-255, 10.1093/ cjres/rsy007.

Jiang, R., Kleer, R., Piller, F.T., 2017. Predicting the future of additive manufacturing: A Delphi study on economic and societal implications of 3D printing for 2030. Technol. Forecast. Soc. Change 117, 84-97, 10.1016/j.techfore.2017.01.006.

Jick, T.D., 1979. Mixing qualitative and quantitative methods: Triangulation in action. Adm. Sci. Q. 602-611.

Johnson, B., Lorenz, E., Lundvall, B.-Å., 2002. Why all this fuss about codified and tacit knowledge? Ind. Corp. Change 11, 245-262. https://doi.org/10.1093/icc/11.2.245.

Katz, M.L., Shapiro, C., 1986. Technology adoption in the presence of network externalities. J. Polit. Econ. 94, 822-841.

Kaufmann, A., Tödtling, F., 2002. How effective is innovation support for SMEs? An analysis of the region of Upper Austria. Technovation 22, 147-159. https://doi.org/ 10.1016/S0166-4972(00)00081-X.

Keith, D.W., Parson, E., Morgan, M.G., 2010. Research on global sun block needed now. Nature 463, 426-427.

Kellner, T., 2017. GE is building the world's largest 'Additive' machine for 3D printing metals [WWW Document]. GE Rep. URL http://www.ge.com/reports/ge-buildin g-worlds-largest-additive-machine-3d-printing-metals/ (accessed 9.9.17).

Kerns, J., 2016. Replacing metal with plastic [WWW Document]. Mach. Des. URL. htt p://www.machinedesign.com/materials/replacing-metal-plastic (accessed 5.27.17).

Kirchhoff, B.A., Merges, M.J., Morabito, J., 2001. A value creation model for measuring and managing the R\&D portfolio. Eng. Manag. J. 13, 19-22. https://doi.org/ 10.1080/10429247.2001.11415101.

Krugman, P., 1979. A model of innovation, technology transfer, and the world distribution of income. J. Polit. Econ. 87, 253-266.

Laureijs, R.E., Roca, J.B., Narra, S.P., Montgomery, C., Beuth, J.L., Fuchs, E.R.H., 2017 Metal additive manufacturing: cost competitive beyond low volumes. J. Manuf. Sci. Eng. 139, 081010, 10.1115/1.4035420.

Laursen, K., 2015. Revealed comparative advantage and the alternatives as measures of international specialization. Eurasian Bus. Rev. 5, 99-115. https://doi.org/10.1007/ s40821-015-0017-1.

Leary, J., While, A., Howell, R., 2012. Locally manufactured wind power technology for sustainable rural electrification. Energy Policy 43, 173-183. https://doi.org/ 10.1016/j.enpol.2011.12.053.

Lécuyer, C., 2006. Making Silicon Valley: Innovation and the Growth of High Tech, 19301970. MIT Press, Inside technology.

Lee, K., 2005. Making a Technological Catch-up: Barriers and opportunities. Asian J. Technol. Innov. 13, 97-131. https://doi.org/10.1080/19761597.2005.9668610.

Lerner, J., 1996. The Government as Venture Capitalist: The Long-Run Effects of the SBIR Program (No. w5753). National Bureau of Economic Research, Cambridge, MA, 10.3386/w5753.

Li, K., Griffin, D., Yue, H., Zhao, L., 2013. How does culture influence corporate risktaking? J. Corp. Finance 23, 1-22. https://doi.org/10.1016/j.jcorpfin.2013.07.008.
Li, L., 2018. China's manufacturing locus in 2025: With a comparison of "Made-in-China 2025" and "Industry 4.0. Technol. Forecast. Soc. Change 135, 66-74. https://doi. org/10.1016/j.techfore.2017.05.028.

Linear, AMS, 2017. Additive Manufacturing [WWW Document. Linear AMS. URL http:// www.linearams.com/additive-manufacturing/ (accessed 5.26.17).

Lino, F.J., Neto, R.J., 2000. A prototipagem rápida na indústria nacional. Presented at the 2o Encontro Nacional do Colégio de Engenharia Mecânica da Ordem dos Engenheiros, Coimbra 4-15.

Linton, J.D., Walsh, S.T., 2003. From bench to business. Nat. Mater. 2, 287-289. https:// doi.org/10.1038/nmat882.

Linton, J.D., Walsh, S.T., 2008. A theory of innovation for process-based innovations such as nanotechnology. Technol. Forecast. Soc. Change 75, 583-594. https://doi. org/10.1016/j.techfore.2007.02.005.

Lochery, N., 2017. Out of the Shadows: Portugal from Revolution to the Present Day. Bloomsbury, Continuum.

Lynn, L.H., Mohan Reddy, N., Aram, J.D., 1996. Linking technology and institutions: the innovation community framework. Res. Policy 25, 91-106. https://doi.org/ 10.1016/0048-7333(94)00817-5.

Macher, J.T., 2006. Technological development and the boundaries of the firm: a knowledge-based examination in semiconductor manufacturing. Manag. Sci. 52, 826-843. https://doi.org/10.1287/mnsc.1060.0511.

Madrid-Guijarro, A., Garcia, D., Van Auken, H., 2009. Barriers to innovation among spanish manufacturing SMEs. J. Small Bus. Manag. 47, 465-488. https://doi.org/ 10.1111/j.1540-627X.2009.00279.x.

Makkonen, T., 2013. Government science and technology budgets in times of crisis. Res. Policy 42, 817-822, 10.1016/j.respol.2012.10.002.

Malerba, F., 2002. Sectoral systems of innovation and production. Res. Policy, Innovation Systems 31, 247-264. https://doi.org/10.1016/S0048-7333(01)001391.

Malerba, F., Nelson, R., 2011. Learning and catching up in different sectoral systems: evidence from six industries. Ind. Corp. Change 20, 1645-1675, 10.1093/icc/dtr062.

Mamede, R.P., Godinho, M.M., Simões, V.C., 2014. Assessment and Challenges of Industrial Policies in Portugal: Is There a Way Out of the 'Stuck in the Middle' Trap?, in: Structural Change, Competitiveness and Industrial Policy. Painful Lessons from the European Periphery, Routledge, London.

Mani, M., Lane, B., Donmez, A., Feng, S., Moylan, S., Fesperman, R., 2015. Measurement science needs for real-time control of additive manufacturing powder bed fusion Processes (No. NIST IR 8036). National Institute of Standards and Technology.

Mansfield, E., 1961. Technical change and the rate of imitation. Econometrica 29, 741-766. https://doi.org/10.2307/1911817.

Mansfield, E., Lee, J.-Y., 1996. The modern university: contributor to industrial innovation and recipient of industrial R\&D support. Res. Policy 25, 1047-1058. https://doi.org/10.1016/S0048-7333(96)00893-1.

Maresch, D., Gartner, J., 2020. Make disruptive technological change happen - The case of additive manufacturing. Technol. Forecast. Soc. Change 155, 119216, 10.1016/j. techfore.2018.02.009.

Marinakis, Y.D., 2012. Forecasting technology diffusion with the Richards model. Technol. Forecast. Soc. Change 79, 172-179. https://doi.org/10.1016/j. techfore.2011.02.010.

Martin, S., Scott, J.T., 2000. The nature of innovation market failure and the design of public support for private innovation. Res. Policy 29, 437-447. https://doi.org/ 10.1016/S0048-7333(99)00084-0.

Maskell, P., Malmberg, A., 1999. Localised learning and industrial competitiveness. Camb. J. Econ. 23, 167-185.

Matsuo, H., 2015. Implications of the Tohoku earthquake for Toyota's coordination mechanism: Supply chain disruption of automotive semiconductors. Int. J. Prod. Econ. 161, 217-227. https://doi.org/10.1016/j.ijpe.2014.07.010.

Mazzucato, M., 2013. Financing innovation: creative destruction vs. destructive creation. Ind. Corp. Change 22, 851-867, 10.1093/icc/dtt025.

Minho, U., 2016. Inauguração do DONE Lab [WWW Document]. URL https://www. uminho.pt/PT/siga-a-uminho/Paginas/Detalhe-do-evento.aspx?Codigo=49633 (accessed 12.1.16).

Morgan, K., 2007. The learning region: institutions, innovation and regional renewal. Reg. Stud. 41, S147-S159. https://doi.org/10.1080/00343400701232322.

Morton, O., 2006. Solar energy: a new day dawning?: Silicon Valley sunrise. Nature 443, 19-22. https://doi.org/10.1038/443019a.

Mowery, D.C., Nelson, R.R., Martin, B.R., 2010. Technology policy and global warming: why new policy models are needed (or why putting new wine in old bottles won't work). Res. Policy 39, 1011-1023. https://doi.org/10.1016/j.respol.2010.05.008.

Mowery, D.C., Rosenberg, N., 1981. Technical change in the commercial aircraft industry, 1925-1975. Technol. Forecast. Soc. Change 20, 347-358. https://doi.org/ 10.1016/0040-1625(81)90065-2.

Munari, F., Sobrero, M., Malipiero, A., 2012. Absorptive capacity and localized spillovers: focal firms as technological gatekeepers in industrial districts. Ind. Corp. Change 21, 429-462, 10.1093/icc/dtr053.

Murphy, S.V., Atala, A., 2014. 3D bioprinting of tissues and organs. Nat. Biotechnol. 32, 773-785. https://doi.org/10.1038/nbt.2958.

Narayanamurti, V., Anadon, L.D., Breetz, H., Bunn, M., Lee, H., Mielke, E., 2011. Transforming the energy economy: Options for accelerating the commercialization of advanced energy technologies. Energy Technol. Innov. Policy Res. Group Kennedy Sch. Gov. Harv. Univ. Camb. MA.

Nelson, R.R., 1982. Government and Technical Progress: A Cross-Industry Analysis. Pergamon Pr, New York.

Nelson, R.R., 1993. National Innovation systems: a comparative analysis. Oxford University Press. 
Nelson, R.R., 1994. The Co-evolution of technology, industrial structure, and supporting institutions. Ind. Corp. Change 3, 47-63. https://doi.org/10.1093/icc/3.1.47.

Nelson, R.R., Winter, S.G., 1982. An Evolutionary Theory of Economic Change. Harvard University Press.

Ning, F., Cong, W., Hu, Y., Wang, H., 2017. Additive manufacturing of carbon fiberreinforced plastic composites using fused deposition modeling: Effects of process parameters on tensile properties. J. Compos. Mater. 51, 451-462. https://doi.org/ 10.1177/0021998316646169.

North, D.C., Weingast, B.R., 1989. Constitutions and commitment: the evolution of institutions governing public choice in seventeenth-century England. J. Econ. Hist. 49, 803-832. https://doi.org/10.1017/S0022050700009451.

NPR, 2008. Bill gates targets visa rules for tech workers [WWW Document]. NPR.org. URL https://www.npr.org/templates/story/story.php?storyId=88154016 (accessed 3.21.18).

NRC, 2004. Accelerating Technology Transition: Bridging the Valley of Death for Materials and Processes in Defense Systems. National Academies Press, Washington, D.C, $10.17226 / 11108$.

Oakey, R., 1990. New Firms in the Biotechnology Industry: Their Contribution to Innovation and Growth. Thomson Learning, London ; New York.

O'Brien, J., Folta, T., 2009. Sunk costs, uncertainty and market exit: A real options perspective. Ind. Corp. Change 18, 807-833, 10.1093/icc/dtp014.

Oliver, C., 1991. Strategic Responses to Institutional Processes. Acad. Manage. Rev. 16, 145-179. https://doi.org/10.5465/AMR.1991.4279002.

Paik, Y., Woo, H., 2014. Economic downturn and financing innovative startup companies: economic downturn and financing innovative startup companies. Manag. Decis. Econ. 35, 114-128. https://doi.org/10.1002/mde.2646.

Patel, P., Pavitt, K., 1994. Uneven (and Divergent) technological accumulation among advanced countries: evidence and a framework of explanation. Ind. Corp. Change 3 , 759-787. https://doi.org/10.1093/icc/3.3.759.

Perez, C., 2010. The financial crisis and the future of innovation: a view of technical change with the aid of history (The Other Canon Foundation and Tallinn University of Technology Working Papers in Technology Governance and Economic Dynamics No. 28). TUT Ragnar Nurkse School of Innovation and Governance.

Perez, C., Soete, L., 1988. Catching up in technology: entry barriers and windows of opportunity. Tech. Change Econ. Theory. London 458-479.

Petrick, I.J., Simpson, T.W., 2013. 3D printing disrupts manufacturing: how economies of one create new rules of competition. Res.-Technol. Manag. 56, 12-16. https://doi. org/10.5437/08956308X5606193.

Pisano, G.P., 1991. The governance of innovation: vertical integration and collaborative arrangements in the biotechnology industry. Res. Policy 20, 237-249.

Pisano, G.P., 1997. The development factory: unlocking the potential of process innovation. Harvard Business Press.

Polanyi, M., 1958. Personal knowledge; towards a post-critical philosophy. University of Chicago Press.

Pontes, A.J., Gago, P.T., Bártolo, P.J., Soares, R., Pouzada, A.S., 2005. Hibridmolde : a project towards the new mould generation. in: O Molde. Presented at the O Molde, CEFAMOL 16-20.

PORDATA, 2017. Despesas em actividades de investigação e desenvolvimento (I\&D) em \% do PIB: por sector de execução - Portugal [WWW Document]. URL https://www. pordata.pt/Portugal/Despesas+em +actividades+de+investiga $\%$ c $3 \% \mathrm{a} 7 \% \mathrm{c} 3 \% \mathrm{a} 3 \mathrm{o}+\mathrm{e}$ + desenvolvimento $+(\mathrm{I}+\mathrm{D})+\mathrm{em}+$ percentagem + do $+\mathrm{PIB}+$ por + sector + de + execu $\%$ c3\%a7\%c3\%a3o-1133 (accessed 9.9.17).

Porter, M.E., 1996. Competitive advantage, agglomeration economies, and regional policy. Int. Reg. Sci. Rev. 19, 85-90. https://doi.org/10.1177/ 016001769601900208.

Portugal3D, 2015. evento Portugal 3D 2015 | Vamos colocar Portugal a pensar 3D! [WWW Document]. URL http://www.portugal3d.pt/ (accessed 9.14.16).

Qiao, J., Li, Y., Li, L., 2019. Ultrasound-assisted 3D printing of continuous fiber reinforced thermoplastic (FRTP) composites. Addit. Manuf. 30, 100926, 10.1016/j addma.2019.100926.

RAMATI, 2007. Rapid manufacturing of titanium implants. Final Publishable Report (No. NMP2- CT-2003-505954).

Rayna, T., Striukova, L., 2016. From rapid prototyping to home fabrication: how 3D printing is changing business model innovation. Technol. Forecast. Soc. Change 102, 214-224. https://doi.org/10.1016/j.techfore.2015.07.023.

Reis, A., Heitor, M., Amaral, M., Mendonça, J., 2016. Revisiting industrial policy: lessons learned from the establishment of an automotive OEM in Portugal. Technol. Forecast. Soc. Change. 10.1016/j.techfore.2016.04.006.

Rogers, E.M., 2003. Diffusion of Innovations. Free Press, New York, 5th Edition, 5 edition.

Rosenberg, N., 1972. Factors affecting the diffusion of technology. Explor. Econ. Hist. 10, 3-33. https://doi.org/10.1016/0014-4983(72)90001-0.

Royo, S., Christopher Manuel, P., 2003. Some lessons from the fifteenth anniversary of the Accession of Portugal and Spain to the European Union. South Eur. Soc. Polit. 8, 1-30, 10.1080/13608740808539641.

Said, M.F., Adham, K.A., Abdullah, N.A., Hänninen, S., Walsh, S.T., 2012. Incubators and government policy for developing IT industry and region in emerging economies 32 .

Santos, C., Mehrsai, A., Barros, A.C., Araújo, M., Ares, E., 2017. Towards Industry 4.0: an overview of European strategic roadmaps. Procedia Manuf., Manuf. Eng. Soc. Int. Conf. 13, 972-979, 2017, MESIC 2017, 28-30 June 2017, Vigo (Pontevedra), Spain10.1016/j.promfg.2017.09.093.

Santos, C.D., 2009. Recovering the sunk costs of R\&D: the moulds industry case [WWW Document]. URL http://cep.lse.ac.uk/ (accessed 10.28.17).

Sanz-Menéndez, L., Cruz-Castro, L., 2003. Coping with environmental pressures: public research organisations responses to funding crises. Res. Policy 32, 1293-1308. https://doi.org/10.1016/S0048-7333(02)00120-8.
Sargent, J., 2012. The Obama Administration's proposal to establish a national network for manufacturing innovation. Fed. Publ.

Saunders, S., 2017a. EOS and audi announce new development partnership focusing on metal additive manufacturing. 3D Printcom Voice 3D Print. Addit. Manuf. URL https://3dprint.com/162622/eos-audi-development-partnership/ (accessed 5.26.17).

Saunders, S., 2017b. EOS expands academia program, enhancing additive manufacturing training offerings. 3DPrintcom Voice 3D Print. Addit. Manuf. URL https://3dprint. com/183632/eos-expanded-academia-program/ (accessed 8.31.17).

Sawik, T., 2019. Disruption mitigation and recovery in supply chains using portfolio approach. Omega 84, 232-248, 10.1016/j.omega.2018.05.006.

Schilling, M.A., 1998. Technological lockout: an integrative model of the economic and strategic factors driving technology success and failure. Acad. Manag. Acad. Manag. Rev. Briarcliff Manor 23, 267-284.

Schuelke-Leech, B.-A., 2014. Volatility in federal funding of energy R\&D. Energy Policy 67, 943-950, 10.1016/j.enpol.2013.12.057.

Shahrubudin, N., Lee, T.C., Ramlan, R., 2019. An overview on 3D printing technology: technological, materials, and applications. Procedia Manuf. The 2nd International Conference on Sustainable Materials Processing and Manufacturing, SMPM 2019, 810 March 2019, Sun City, South Africa 35, 1286-1296, 10.1016/j. promfg.2019.06.089.

Shapiro, C., Varian, H.R., 1999. The art of standards wars. Manag. Modul. Age 247-272.

Singh, K., 1997. The impact of technological complexity and interfirm cooperation on business survival. Acad. Manage. J. 40, 339-367.

Slovic, P., 1987. Perception of risk. Science 236, 280-285, 10.1126/science.3563507.

Stewart, R.B., 1981. Regulation, innovation, and administrative law: a conceptual framework. Calif. Law Rev. 69, 1256-1377. https://doi.org/10.2307/3480247.

Sun, H., Jia, Y., Dong, H., Dong, D., Zheng, J., 2020. Combining additive manufacturing with microfluidics: an emerging method for developing novel organs-on-chips. Curr. Opin. Chem. Eng. 28, 1-9, 10.1016/j.coche.2019.10.006.

Tassey, G., 1997. The Economics of R\&D Policy. Praeger, Westport, Conn.

Taylor, M., Taylor, A., 2012. The technology life cycle: Conceptualization and managerial implications. Int. J. Prod. Econ., Sustain. Dev. Manuf. Serv. 140, 541-553. https://doi.org/10.1016/j.ijpe.2012.07.006.

Taylor, M.Z., 2016. The Politics of Innovation: Why Some Countries Are Better Than Others at Science and Technology, 1 edition. Oxford University Press, New York, NY.

Teece, D., Pisano, G., 1994. The dynamic capabilities of firms: an Introduction. Ind. Corp. Change 3, 537-556, 10.1093/icc/3.3.537-a.

Tepper, F., 2017. Adidas' latest 3D-printed shoe puts mass production within sight. TechCrunch. URL http://social.techcrunch.com/2017/04/07/adidas-latest-3dprinted-shoe-puts-mass-production-within-sight/ (accessed 5.27.17).

The White House, 2012. We Can't Wait: obama administration announces new public private partnership to support [WWW Document]. whitehouse.gov. URL https:// obamawhitehouse.archives.gov/the-press-office/2012/08/16/we-can-t-waitobama-administration-announces-new-public-private-partners (accessed 11.23.17).

Thomke, S., von Hippel, E., Franke, R., 1998. Modes of experimentation: an innovation process-and competitive-variable. Res. Policy 27, 315-332. https://doi.org/ 10.1016/S0048-7333(98)00041-9.

Thomke, S.H., 1998. Simulation, learning and R\&D performance: Evidence from automotive development. Res. Policy 27, 55-74, 10.1016/S0048-7333(98)00024-9.

Tierney, R., Hermina, W., Walsh, S., 2013. The pharmaceutical technology landscape: a new form of technology roadmapping. Technol. Forecast. Soc. Change 80, 194-211. https://doi.org/10.1016/j.techfore.2012.05.002. World problems, Emerging technologies and Creative Enterprise.

Tolfree, D., Walsh, S.T., 2018. An introduction to the field of commercializing emerging materials manufacturing technologies in an IoT world. Transl. Mater. Res. 5, 024002, 10.1088/2053-1613/aac43a.

Tornatzky, L.G., Klein, K.J., 1982. Innovation characteristics and innovation adoptionimplementation: a meta-analysis of findings. IEEE Trans. Eng. Manag. EM-29 28-45, 10.1109/TEM.1982.6447463.

Tyre, M.J., von Hippel, E., 1997. The situated nature of adaptive learning in organizations. Organ. Sci. 8, 71-83. https://doi.org/10.1287/orsc.8.1.71.

Vanhove, N., 2018. Regional Policy, 1st ed. A European Approach, Routledge. 10.4324/ 9780429447921.

Veloso, F., Soto, J.M., 2001. Incentives, infrastructure and institutions: perspectives on industrialization and technical change in late-developing nations. Technol. Forecast. Soc. Change 66, 87-109. https://doi.org/10.1016/S0040-1625(99)00065-7.

von Hippel, E., 1994. Sticky information" and the locus of problem solving: implications for innovation. Manag. Sci. 40, 429-439. https://doi.org/10.1287/mnsc.40.4.429.

Walsh, S.T., 2004. Roadmapping a disruptive technology: A case study: The emerging microsystems and top-down nanosystems industry. Technol. Forecast. Soc. Change, Roadmapping: From Sustainable to Disruptive Technologies 71, 161-185. https:// doi.org/10.1016/j.techfore.2003.10.003.

Weyant, J.P., 2011. Accelerating the development and diffusion of new energy technologies: Beyond the "valley of death. Energy Econ 33, 674-682. https://doi. org/10.1016/j.eneco.2010.08.008.

Wohlers Associates, 2016. 3D printing and additive manufacturing state of the industry. Annual Worldwide Progress Report.

Wohlers, T., 2005. History of additive manufacturing.

Wohlers, T., Gornet, T., 2016. History of additive manufacturing.

Wonglimpiyarat, J., 2016. Government policies towards Israel's high-tech powerhouse. Technovation. https://doi.org/10.1016/j.technovation.2016.02.001.

World Bank, 2016. Wold DataBank [WWW Document]. URL http://databank.worldbank. org/data/ (accessed 9.15.16).

Yan, X., Gu, P., 1996. A review of rapid prototyping technologies and systems. Comput.Aided Des 28, 307-318. https://doi.org/10.1016/0010-4485(95)00035-6. 
Yang, C.-H., Motohashi, K., Chen, J.-R., 2009. Are new technology-based firms located on science parks really more innovative? Res. Policy $38,77-85$. https://doi.org/ 10.1016/j.respol.2008.09.001.

Yin, R.K., 2013. Case study research: design and methods. SAGE Publications.

Younglai, R., Bohan, C., 2013. Silicon Valley intensifies lobbying on immigration bill. Reuters.

Zeitlin, J., Herrigel, G., 2000. Americanization and Its limits: reworking US technology and management in Post-war Europe and Japan. Oxford University Press.

Zucker, L.G., Darby, M.R., Armstrong, J.S., 2002. Commercializing Knowledge: university science, knowledge capture, and firm performance in biotechnology. Manag. Sci. 48, 138-153. https://doi.org/10.1287/mnsc.48.1.138.14274.

Jaime Bonnin Roca is an Assistant Professor of Innovation and Entrepreneurship in the Innovation, Technology Entrepreneurship and Marketing Group, at Eindhoven University of Technology, Netherlands. He completed his PhD in Engineering and Public Policy in a dual program between Carnegie Mellon University (USA) and Universidade de Lisboa (Portugal). His research focuses on the role of uncertainty in entrepreneurship and technology adoption, especially in manufacturing industries, and the role of public organizations and policy in shaping that uncertainty.

Parth Vaishnav is an Assistant Professor in Sustainable Systems at the School for Environment and Sustainability at the University of Michigan. He has worked on the distribution of subsidies, benefits, and costs of rooftop solar photovoltaic installations in the U. S., on problems related to the decarbonization of freight transport, as well as on the economics of additive manufacturing. His research focuses on the practical constraints-economic, operational, and behavioral—on the deployment of technology to solve social problems. He is Associate Director for Research Planning and Outreach at the NSF-supported center for Climate and Energy Decision-Making.
M. Granger Morgan is the Hamerschlag University Professor of Engineering at Carnegie Mellon University (www.epp.cmu.edu) where he holds appointments in three academic units: the Department of Engineering and Public Policy (for which he was the founding Department Head); the Department of Electrical and Computer Engineering; and the H. John Heinz III College. He co-directs CMU's Center for Climate and Energy Decision Making (www.cedmcenter.org) and the CMU Electricity industry Center (www.cmu. edu/electricity). His research addresses problems in science, technology, and public policy. Morgan is a Member of the National Academy of Sciences and of the American Academy of Arts and Sciences.

Erica R.H. Fuchs is a Professor in the Department of Engineering and Public Policy at Carnegie Mellon University, and was the founding Faculty Director of Carnegie Mellon University's Manufacturing Futures Initiative - an initiative across six schools aimed to revolutionize the commercialization and local production of advanced manufactured products. Her research focuses on the development, commercialization and global manufacturing of emerging technologies, and national policy in that context. She currently serves on the National Academies' National Materials and Manufacturing Board; the World Economic Forum's Future of Production Global Futures Council; and the Academic Advisory Board for M.I.T.'s Institute for Data, Systems, and Society.

Joana Mendonça is an Assistant Professor at the Engineering and Management Department at IST/University of Lisbon. She is a Scientific Director of the Carnegie Mellon Portugal Partnership and scientific coordinator at CEiiA. Her research focuses on processes of new technology commercialization, industrial development and in the role of skills and human capital in these processes. Previously, she was an assistant to the Minister for Economy, Deputy Director at the Directorate for Education and Science Statistics (DGEEC), and assistant to the Secretary of State for Science, Technology and Higher Education. 